\title{
26. NANNOFOSSIL BIOSTRATIGRAPHY, LEG 22, DEEP SEA DRILLING PROJECT
}

\author{
Stefan Gartner, Jr., Rosenstiel School of Marine and Atmospheric Science, University of Miami, Coral Gables, Florida
}

\section{INTRODUCTION}

Calcareous nannofossils were recovered at every site drilled during Leg 22. Not all sites, however, yielded equally good assemblages, and, at some sites only a small fraction of the interval cored and drilled yielded calcareous sediments. In general, the most representative calcareous nannofossil successions were recovered at the shallower sites, particularly those along the crest of Ninetyeast Ridge (Sites 214, 216, and 217). Poorest recovery of calcareous nannofossils was from the deepest part of the Indian Ocean, in the Wharton Basin east of Ninetyeast Ridge (Sites 211, 212 , and 213). This is not surprising as the last three sites are all well below 5000 meters, and one site (212) is situated well below 6000 meters. This same site did yield calcareous sediments over much of the interval cored, but the section is by no means representative. In fact, this site has a most unusual history of carbonate deposition in that all the calcareous sediments seem to have been transported to this site by currents, and probably none were deposited as normal pelagic sediments from the water column above. One site west of Ninetyeast Ridge (215) also was more than 5000 meters deep and only part of the section was calcareous. Finally, the site drilled on the Bengal Fan (218) yielded calcareous material throughout the interval cored, but because of the large proportion of detrital constituents, the calcareous nannofossils and other pelagic constituents were diluted to such an extent in some parts of the interval that they were only rarely encountered.

\section{NANNOFOSSIL ZONATION}

The calcareous nannofossil zonation used during Leg 22 is indicated below. With the exception of the Discoaster asymmetricus Zone, all of the zones listed were readily recognized in the sediments recovered in the Indian Ocean. Recognition of the Discoaster asymmetricus Zone depends on the identification of Discoaster asymmetricus and Ceratolithus tricorniculatus s.l. in an interval where both species may be relatively rare, and hence the zone may go undetected in a preliminary examination. Despite this fact, it has not been excluded from any scheme presented here. Data for constructing the zonal succession and the zonal names are drawn from all available sources. In choosing from among the various zonations, preference was given to zones which are readily recognized in oceanic as well as in hemipelagic sediments. Provincial species, especially those restricted to hemipelagic sediments, make poor zonal markers in oceanic deposits. Notorious among the latter are the mid-Tertiary helicopontosphaeras, pentaliths, holococcoliths, Ericsonia subdisticha, and some Miocene asteroliths (e.g., Discoaster kugleri).
The late Neogene zonation Emiliania huxleyi to Discoaster quinqueramus is essentially that proposed by Gartner, 1969 (see also Gartner, 1973, for a detailed chronology). The remaining Tertiary zones are compiled chiefly from Bramlette and Wilcoxon (1967); Hay et al. (1967); Hay and Mohler (1967); Gartner (1969; 1971); Martini and Worsley (1970); Martini (1970; 1971); Roth (1970); and Bukry (1971). Because many of these zones are used in a slightly modified sense, a brief characterization is given below for all nannofossil zones used in this volume.

\section{Emiliania huxleyi Zone}

The interval of occurrence of Emiliania huxleyi: This zone spans somewhat less than 200,000 years.

\section{Gephyrocapsa Zone}

The interval from the last occurrence of Pseudoemiliania lacunosa to the first occurrence of Emiliania huxleyi.

\section{Pseudoemiliania lacunosa Zone}

The interval from the last occurrence of Discoaster brouweri to the last occurrence of Pseudoemiliania lacunosa.

\section{Discoaster brouweri Zone}

The interval from the last occurrence of Discoaster surculus to the last occurrence of Discoaster brouweri. The top of this zone corresponds very closely to the Pliocene-Pleistocene boundary as commonly recognized in deep-sea sediments.

\section{Discoaster surculus Zone}

The interval from the last occurrence of Reticulofenestra pseudoumbilica to the last occurrence of Discoaster surculus.

\section{Reticulofenestra pseudoumbilica Zone}

The interval from the last occurrence of nonbirefringent ceratoliths (chiefly Ceratolithus tricorniculatus and Ceratolithus primus) to the last occurrence of Reticulofenestra pseudoumbilica. The top of this zone may be difficult to determine at times because Reticulofenestra pseudoumbilica becomes quite rare and may be represented by only small specimens. 


\section{Discoaster asymmetricus Zone}

The interval from the first occurrence of Discoaster asymmetricus to the last occurrence of nonbirefringent ceratoliths. Discoaster asymmetricus as well as nonbirefringent ceratoliths may be rare in this interval in some types of pelagic sediment. Consequently, this zone may be difficult to recognize at times.

\section{Discoaster mohleri Zone}

The interval from the first occurrence of Discoaster mohleri to the first occurrence of Discoaster multiradiatus.

\section{Heliolithus kleinpelli Zone}

The interval from the first occurrence of Heliolithus kleinpelli to the first occurrence of Discoaster mohleri.

Fasciculithus tympaniformis Zone

The interval from the first occurrence of Fasciculithus tympaniformis to the first occurrence of Heliolithus kleinpelli.

\section{Cydococcolithina robusta Zone}

The interval from the first occurrence of Cyclococcolithina robusta to the first occurrence of Fasciculithus tympaniformis. Ellipsolithus macellus and Chiasmolithus bidens first occur near the bottom of this zone, and the last-named species enjoys by far the most cosmopolitan distribution of the three. Unfortunately, early specimens of this species are frequently identified as Chiasmolithus danicus with the light microscope.

\section{Cruciplacolithus tenuis Zone}

The interval from the first occurrence of Cruciplacolithus tenuis to the first occurrence of Cyclococcolithina robusta. In oceanic calcareous oozes the Tertiary record generally does not extend below this level, so that sediments of the Cruciplacolithus tenuis zone are underlain by Upper Cretaceous deposits.

\section{Ceratolithus rugosus Zone}

The interval from the first occurrence of Ceratolithus rugosus to the first occurrence of Discoaster asymmetricus.

\section{Ceratolithus tricorniculatus Zone}

The interval from the last occurrence of Discoaster quinqueramus to the first occurrence of Ceratolithus rugosus. The Miocene-Pliocene boundary falls within this zone.

\section{Discoaster quinqueramus Zone}

The interval from the first occurrence of nonbirefringent ceratoliths (including but not limited to Ceratolithus primus) to the last occurrence of Discoaster quinqueramus.
The base of this zone also corresponds closely to the last occurrence of Discoaster neohamatus.

\section{Discoaster neohamatus Zone}

The interval from the first occurrence of Discoaster neohamatus to the first occurrence of Ceratolithus tricorniculatus. For practical purposes this is a total range zone as the last occurrence of Discoaster neohamatus closely corresponds to the first occurrence of the genus Ceratolithus.

\section{Discoaster hamatus Zone}

The interval from the first occurrence of Discoaster hamatus to the first occurrence of Discoaster neohamatus.

\section{Catinaster coalitus Zone}

The interval from the first occurrence of Catinaster coalitus to the first occurrence of Discoaster hamatus.

\section{Discoaster exilis Zone}

The interval from the last occurrence of Sphenolithus heteromorphus to the first occurrence of Catinaster coalitus. This characterization is a poor one because it relies on the absence of two index species. Cyclicargolithus floridanus and Cyclolithella nitescens both occur within this zone but do not range to the very top of it. The Discoaster kugleri Zone of other authors corresponds to the top of this zone, but as Discoaster kugleri is not a cosmopolitan species the zone is not included.

\section{Sphenolithus heteromorphus Zone}

The interval from the last occurrence of Sphenolithus belemnos to the last occurrence of Sphenolithus heteromorphus. The Helicopontosphaera ampliaperta Zone of other authors corresponds to the lower part of this zone. It is not included here because the marker species, Helicopontosphaera ampliaperta, generally is not found in oceanictype pelagic sediments.

\section{Sphenolithus belemnos Zone}

The interval of the total range of Sphenolithus belemnos.

\section{Triquetrorhabdulus carinatus Zone}

The interval from the first occurrence of Triquetrohabdulus carinatus to the first occurrence of Sphenolithus belemnos. The species Triquetrorhabdulus carinatus seemingly is highly susceptible to heavy calcification, which makes identification uncertain. Hence, identification of the zone also may be difficult.

\section{Sphenolithus ciperoensis Zone}

The interval from the first occurrence of Sphenolithus ciperoensis to the first occurrence of Triquetrorhabdulus carinatus. 


\section{Sphenolithus distentus Zone}

The interval from the first occurrence of Sphenolithus distentus to the first occurrence of Sphenolithus ciperoensis.

\section{Sphenolithus predistentus Zone}

The interval from the last occurrence of Cyclococcolithina formosa to the first occurrence of Sphenolithus distentus.

\section{Cyclococcolithina formosa Zone}

The interval from the last occurrence of Discoaster barbadiensis to the last occurrence of Cyclococcolithinia formosa. The several zones designated for the lower Oligocene interval, all of which are here included in the Cyclococcolithinia formosa Zone, are based on provincial specie (e.g., Helicopontosphaera reticulata, Ericsonia subdisticha, Cyclococcolithus margaritae) and are of little or no use in open ocean pelagic sediments.

\section{Discoaster barbadiensis Zone}

The interval from the last occurrence of Chiasmolithus grandis to the last occurrence of Discoaster barbadiensis.

\section{Chiasmolithus grandis Zone}

The interval from the first occurrence of Reticulofenestra umbilica to the last occurrence of Chiasmolithus grandis. Although Reticulofenestra umbilica is a common, distinctive, and cosmopolitan species, the base of this zone may be difficult to determine at times on the basis of this species because it evolved gradually from similar but smaller species. The separation, therefore, becomes subjective. In oceanic sediments the first occurrence of Bramletteius serraculoides closely corresponds to the base of this zone, but this form is not common in hemipelagic sediments.

\section{Nannotetrina alata Zone}

The interval from the first occurrence of Nannotetrina alata (=Chiphragmalithus quadratus = Chiphragmalithus alatus) to the first occurrence of Reticulofenestra umbilica.

\section{Discoaster sublodoensis Zone}

The interval from the first occurrence of Discoaster sublodoensis to the first occurrence of Nannotetrina alata.

\section{Discoaster lodoensis Zone}

The interval from the last occurrence of Tribrachiatus orthostylus to the first occurrence of Discoaster sublodoensis.

\section{Tribrachiabus orthostylus Zone}

The interval from the last occurrence of Discoaster diastypus to the last occurrence of Tribrachiatus orthostylus.

\section{Discoaster diastypus Zone}

The interval of the total range of Discoaster diastypus.

Discoaster multiradiatus Zone

The interval from the first occurrence of Discoaster multiradiatus to the first occurrence of Discoaster diastypus.

Pre-Tertiary sediments recovered during Leg 22 are assignable to the uppermost four Upper Cretaceous nannofossil zones which are characterized as follows.

\section{Nephrolithus frequens Zone}

The interval from the first occurrence of Nephrolithus frequens to the Cretaceous-Tertiary boundary, which is marked by the disappearance of nearly all Upper Cretaceous species.

\section{Lithraphidites quadratus Zone}

The interval from the first occurrence of Lithraphidites quadratus to the first occurrence of Nephrolithus frequens.

\section{Tetralithus nitidus trifidus Zone}

The interval from the first occurrence of Tetralithus nitidus trifidus to the first occurrence of Lithraphidites quadratus.

\section{Eiffellithus augustus Zone}

The interval from the first occurrence of Broinsonia parca to the first occurrence of Tetralithus nitidus trifidus.

The nannofossil zonal succession in the Indian Ocean, and more specifically, in the equatorial region of the Ninetyeast Ridge, is very similar to the nannofossil zonal succession found by Bukry (1972) for the North Atlantic sediment recovered on DSDP Leg 12. This seems puzzling because the two areas in question, i.e., the northern North Atlantic and the Indian oceans, are separated as much from one another as is possible. Moreover, one of the areas is tropical and the other is cool temperate to subarctic. It is tempting to smugly point to this similarity of nannofossil zonal successions as proof of the universality of nannofossil biostratigraphy, but some of the similarities go beyond that. This is especially true for some Late Cretaceous and early Tertiary assemblages. The late Maastrichtian index species Nephrolithus frequens is best known from northern Europe. Worsley and Martini (1970) suggest that this species is a cold water form and, therefore, is absent in low latitude late Maastrichtian sediments. On Leg 22 Nephrolithus frequens was recovered on sites very close to the present-day equator, although a Late Cretaceous reconstruction places these same sites at much higher latitudes in the southern hemisphere. Thus, Nephrolithus frequens, like several modern coccolithophores, probably had a bipolar distribution.

The early Tertiary species, Chiasmolithus danicus, represents a similar case. This form has been reported from several localities, but only specimens from northern Europe 
and from the North Atlantic can be assigned to this species unequivocally. In lower Paleocene sediments of the Ninetyeast Ridge this species is common, and again the early Tertiary position of the Indian plate has to be invoked to account for the occurrence of this seemingly high latitude form. A bipolar distribution of this species also seems reasonable.

Thus, for the Late Cretaceous and early Tertiary the similarity of the zonal succession in the North Atlantic and Indian oceans is not at all unreasonable, especially if it is kept in mind that the Tethyan seaway connected the two oceans during Cretaceous and early Tertiary time.

\section{RESULTS AND DISCUSSION}

In Figures 1 through 8 are presented checklists of the calcareous nannofossils recovered at each of the sites drilled during Leg 22. These checklists have been compiled from shipboard data and from subsequent examinations. The latter were directed primarily at determining the limits of occurrence of key index species, so that the biostratigraphic framework for each site could be as accurate as possible. The checklists are by no means comprehensive, although they may be considered as representative of the nannofossils contained in a particular sample. In Figure 9 are summarized the age assignments made on the basis of calcareous nannofossils of sediments recovered during Leg 22. For additional discussion of the results, the reader is referred also to the biostratigraphy section of each site report.

Four sites $(211,212,213$, and 215$)$ were located below the present calcium carbonate compensation depth. The calcareous sediments recovered at these sites can be interpreted to be either allochthonous in origin, i.e., they were transported to their present location by currents or turbidity flows, or, that at certain times the sites were above the calcium carbonate compensation depth. For Site 211 an allochthonous origin is suggested by possible current bedding of the sediment. On the other hand, deposition below the lysocline is suggested by the considerable solution of most nannofossils, though if the probable Late Cretaceous high latitude location of this site is taken into account, this considerable solution does not necessarily require deposition at great depth. Moreover, the low diversity of the nannofossil assemblage at this site -10 species in an interval that normally yields upward of 50 species-can be explained, at least partially, by this same high latitude location, which is postulated in most Late Cretaceous reconstructions of the Indian Ocean. Perhaps a most reasonable explanation for the calcareous nannofossils recovered at Site 211 is that they were probably deposited at less than abyssal depths in a high latitude sea and may have been redeposited by current action.

For Site 212 the calcareous sediments almost certainly have to be allochthonous. Two mechanisms for redeposition are postulated; turbidity currents probably were the major transporting agency during the last 12 million years (Cores 1 through 10). This is suggested by a general mixing of the sediment, so that the major proportion of the fossils becomes younger upward in the section, although there is a constant and significant proportion of older fossils mixed

\begin{tabular}{|c|c|c|c|c|c|c|c|c|c|c|}
\hline Sample & 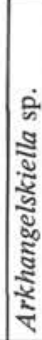 & 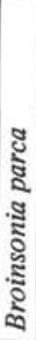 & & 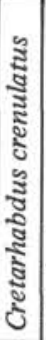 & 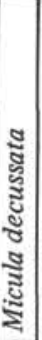 & 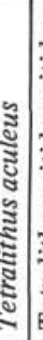 & 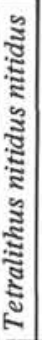 & 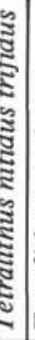 & & 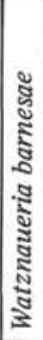 \\
\hline $211-12-2,123 \mathrm{~cm}$ & & & & & $\mathrm{X}$ & & $\mathrm{x}$ & $\mathrm{x}$ & & \\
\hline $211-12-2,146 \mathrm{~cm}$ & & $\mathrm{X}$ & & & $\mathrm{x}$ & $\mathrm{x}$ & $\mathrm{x}$ & $\mathrm{x}$ & & $\mathrm{X}$ \\
\hline $211-12-3,25 \mathrm{~cm}$ & & $\mathrm{X}$ & & & $\mathrm{x}$ & $\mathrm{x}$ & $\mathrm{x}$ & $\mathrm{x}$ & & $\mathrm{x}$ \\
\hline $211-12, \mathrm{CC}$ & & & & & $\mathrm{x}$ & & & $\mathrm{x}$ & & $\mathrm{X}$ \\
\hline $211-13-1,50 \mathrm{~cm}$ & & $\mathrm{X}$ & & & $\mathrm{x}$ & & $\mathrm{x}$ & & & \\
\hline $211-13-1,80 \mathrm{~cm}$ & & $\mathrm{x}$ & & & $\mathrm{x}$ & $\mathrm{x}$ & $\mathrm{x}$ & & & $\mathrm{x}$ \\
\hline $211-13-1,100 \mathrm{~cm}$ & & & & & $\mathrm{x}$ & & & & & \\
\hline $211-13-1,120 \mathrm{~cm}$ & $\mathrm{X}$ & $\mathrm{X}$ & & $\mathrm{x}$ & $\mathrm{x}$ & $\mathrm{x}$ & & & & $\mathrm{X}$ \\
\hline $211-13-1,140 \mathrm{~cm}$ & & & & & $\mathrm{x}$ & & & & & $\mathrm{X}$ \\
\hline $211-13, \mathrm{CC}$ & & $\mathrm{x}$ & $\mathrm{X}$ & & $\mathrm{x}$ & & $\mathrm{x}$ & & & $\mathrm{x}$ \\
\hline $211-14-1,58 \mathrm{~cm}$ & & $\mathrm{x}$ & & & $\mathrm{x}$ & & $\lambda$ & & & \\
\hline
\end{tabular}

Figure 1. Checklist of calcareous nannofossils recovered at Site 211.

in, but with a notable lack of sorting of the sediment. Prior to that time, redeposition probably was affected chiefly by bottom currents which eroded the calcareous sediments elsewhere and carried them in suspension as a nepheloid layer. The short time intervals represented by the considerable thicknesses of calcareous sediments of early middle Miocene, middle Eocene, and Late Cretaceous age: sorting of the sediments; and selective solution taken collectively suggest that all these sediments probably were deposited below the regional calcium carbonate compensation depth in a local pocket where for some peculiar reason the bottom waters were nearly saturated with calcium carbonate.

Sites 213 and 215 are treated together because their sedimentary history seems very similar even though they are on opposite sides of the Ninetyeast Ridge. The upper Miocene to Recent interval is represented by siliceous sediments; the lower Eocene to upper Miocene interval by barren zeolitic clays; and the lower Eocene to basement interval is calcareous. At each site the oldest sediment above basement is Paleocene in age. Towards the top of the calcareous interval, solution effects increase. It seems reasonable that the calcareous sediments at both of these sites were deposited above the calcium carbonate compensation depth, as there is no evidence of slumping or turbidity current deposition. Following the reasoning of Berger (1972), a likely model is that when the crust at these two sites was formed, it was at a much shallower depth in accordance with the crustal elevation-sea-floor spreading model of Menard (1969) and of Sclater, Anderson, and Bell (1971); and only after the crust had moved some distance from the spreading center, did it subside below the regional calcium carbonate compensation depth. If it is assumed that both sites originated at the average ridge crest elevation of 2700 meters and that subsidence occurred at a rate of 1000 meters during the first 10 m.y. and another 1000 


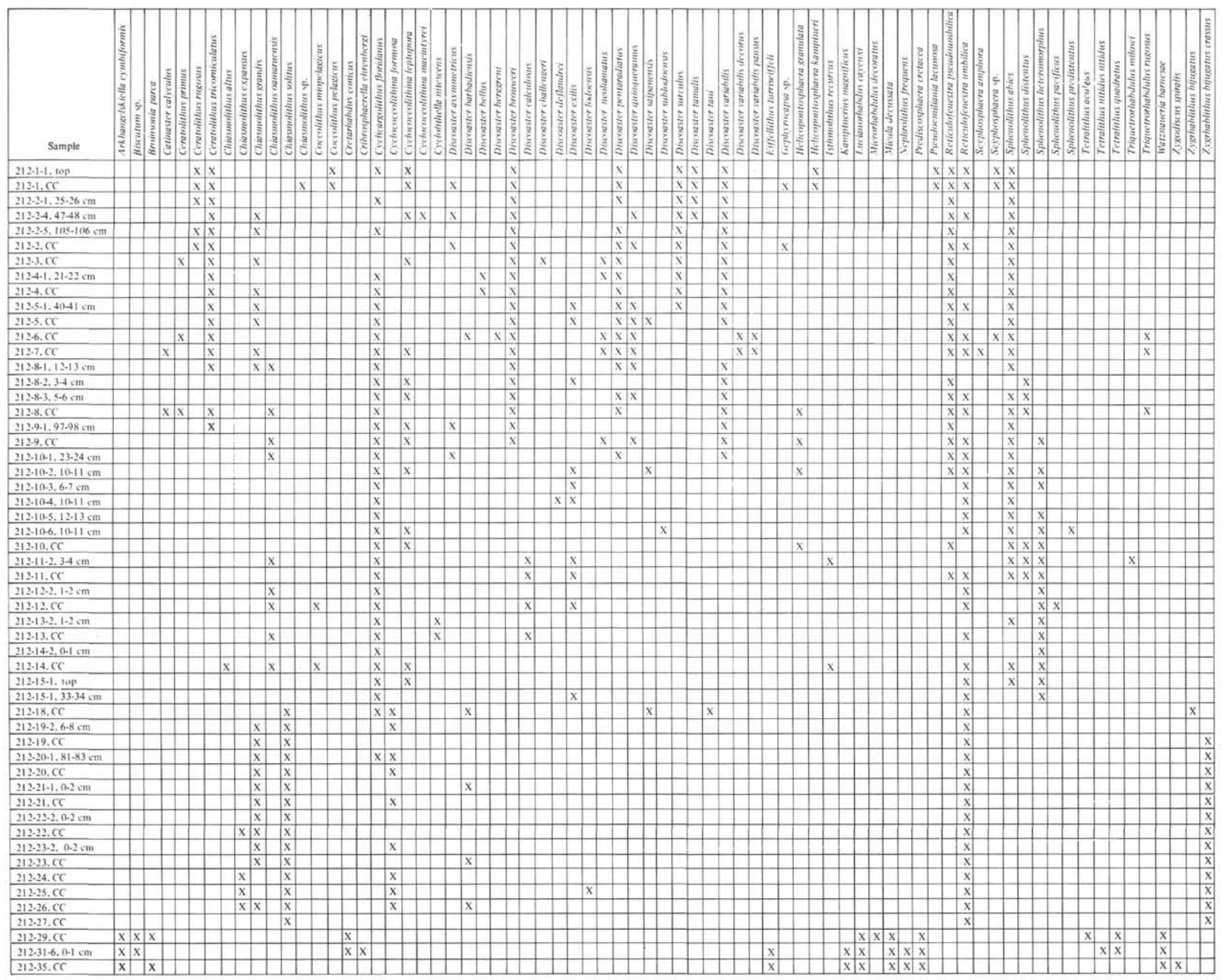

Figure 2. Checklist of calcareous nannofossils recovered at Site 212. 


\begin{tabular}{|c|c|c|c|c|c|c|c|c|c|c|c|c|c|c|c|c|c|c|c|c|c|c|c|c|c|}
\hline Sample & 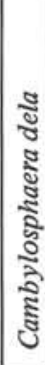 & 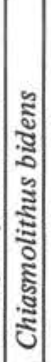 & 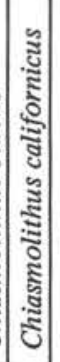 & 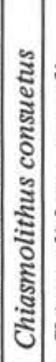 & 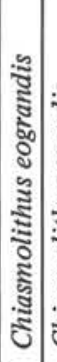 & 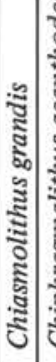 & 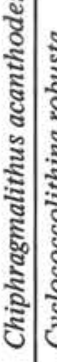 & 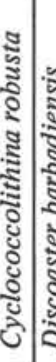 & 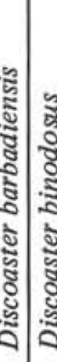 & 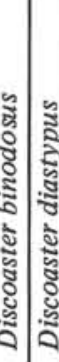 & 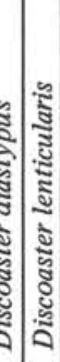 & 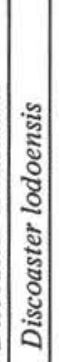 & 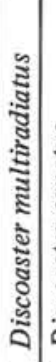 & 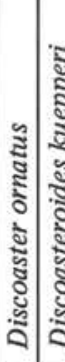 & 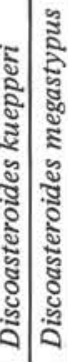 & 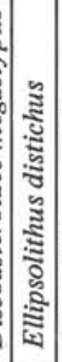 & 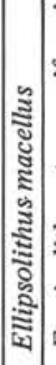 & 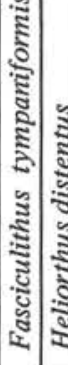 & 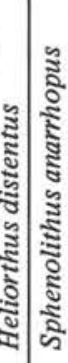 & 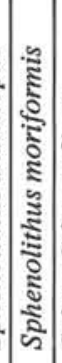 & 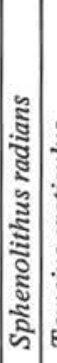 & 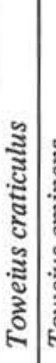 & (2) & 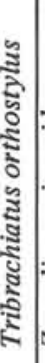 & 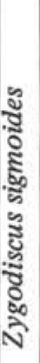 \\
\hline $213-14-5,3-4 \mathrm{~cm}$ & & & & & & & & & & & & $\mathrm{x}$ & & & & & & & & & & & & $\mathrm{X}$ & \\
\hline $213-14-5,50-51 \mathrm{~cm}$ & & & & & & & & & $\mathrm{X}$ & & & $\mathrm{X}$ & & & $\mathrm{X}$ & & & & & & & & & $\mathrm{X}$ & \\
\hline $213-14-5,100-101 \mathrm{~cm}$ & & & & & & & & & $\mathrm{X}$ & & & $\mathrm{x}$ & & & & & & & & & & & & $\mathrm{X}$ & \\
\hline $213-14-6,10-11 \mathrm{~cm}$ & & & & & & & & & $\mathrm{X}$ & & & $\mathrm{X}$ & & & & & & & & & & & & $\mathrm{X}$ & \\
\hline $213-14-6,50-51 \mathrm{~cm}$ & & & & & & & & & $\mathrm{X}$ & & & $\mathrm{X}$ & & & & & & & & $\mathrm{X}$ & & & & $\mathrm{X}$ & \\
\hline $213-14-6,100-101 \mathrm{~cm}$ & & & & & & & & & $\mathrm{X}$ & $\mathrm{X}$ & $\bar{x}$ & $\mathrm{X}$ & & & & & & & & $\mathrm{X}$ & $\mathrm{X}$ & & & $\mathrm{X}$ & \\
\hline $213-14-6,140-141 \mathrm{~cm}$ & $\mathrm{X}$ & & & & & $\mathrm{X}$ & & & $\mathrm{X}$ & $\mathrm{X}$ & $\bar{x}$ & $\mathrm{X}$ & & & & & & & & $\mathrm{X}$ & $\mathrm{X}$ & & & $\mathrm{X}$ & \\
\hline 213-14, CC & $\mathrm{X}$ & & & & & & & & & $\mathrm{X}$ & $\bar{K}$ & $\mathrm{X}$ & & & & & & & & & $\mathrm{X}$ & & & $\bar{X}$ & \\
\hline $213-15-1,120-121 \mathrm{~cm}$ & $\mathrm{X}$ & & $\mathrm{X}$ & & & & $\mathrm{X}$ & & & $\mathrm{X}$ & $\underline{K}$ & $\mathrm{X}$ & & & & & & & & & $\mathrm{X}$ & & & $\mathrm{X}$ & \\
\hline $213-15-3,2-3 \mathrm{~cm}$ & $\mathrm{X}$ & & $\mathrm{X}$ & & & & $\mathrm{X}$ & & $\mathrm{X}$ & \begin{tabular}{l|l}
$\mathrm{X}$ & $\mathrm{X}$ \\
\end{tabular} & $\bar{K}$ & $\mathrm{X}$ & & & \begin{tabular}{l|l|}
$X$ & $X$ \\
\end{tabular} & & & & & & $\mathrm{X}$ & & \begin{tabular}{l|l}
$\mathrm{X}$ & $\mathrm{X}$ \\
\end{tabular} & $\mathrm{X}$ & \\
\hline $213-15-4,25-26 \mathrm{~cm}$ & $\mathrm{X}$ & & $\mathrm{X}$ & & & & $\bar{X}$ & & & $\mathrm{X}$ & K & $\mathrm{X}$ & & & \begin{tabular}{l|l|}
$\mathrm{X}$ & $\mathrm{X}$ \\
\end{tabular} & & $\mathrm{X}$ & & & & $\mathrm{X}$ & & \begin{tabular}{l|l}
$X$ & $X$ \\
\end{tabular} & $\bar{X}$ & \\
\hline $213-15-4,70-71 \mathrm{~cm}$ & & & $\mathrm{X}$ & & & & $\mathrm{X}$ & & $\mathrm{X}$ & \begin{tabular}{l|l}
$\mathrm{X}$ & $\mathrm{X}$ \\
$\mathrm{n}$
\end{tabular} & $\mathrm{K}$ & & & & $\mathrm{X}$ & & $\mathrm{X}$ & & & & $\mathrm{X}$ & & \begin{tabular}{l|l}
$X$ & $X$ \\
\end{tabular} & $\bar{X}$ & \\
\hline $213-15-5,9-10 \mathrm{~cm}$ & $\mathrm{X}$ & & $\mathrm{X}$ & & $\mathrm{X}$ & & & & & \begin{tabular}{l|l}
$x$ \\
$X$
\end{tabular} & $\frac{1}{x}$ & & $\mathrm{X}$ & & $\mathrm{X}$ & & $\mathrm{X}$ & & $\mathrm{X}$ & $\mathrm{X}$ & $\mathrm{X}$ & & \begin{tabular}{l|l}
$X$ \\
\end{tabular} & $\mathrm{X}$ & \\
\hline $213-15-6,32-33 \mathrm{~cm}$ & & $\mathrm{x}$ & $\mathrm{X}$ & & $\mathrm{X}$ & & & & & $\mathrm{X}$ & $x$ & $\mathrm{X}$ & $\mathrm{X}$ & & \begin{tabular}{l|l|}
$X$ & $X$ \\
\end{tabular} & & $\mathrm{X}$ & & & $\mathrm{X}$ & & & \begin{tabular}{l|l}
$\mathrm{X}$ & $\mathrm{X}$ \\
\end{tabular} & $\mathrm{X}$ & \\
\hline $213-15, \mathrm{CC}$ & & & $\mathrm{X}$ & & $\mathrm{X}$ & & & & & $\mathrm{X}$ & $\underline{x}$ & & $\mathrm{X}$ & & & $\mathrm{X}$ & $\mathrm{X}$ & & $\mathrm{X}$ & & $\mathrm{X}$ & & & $\bar{X}$ & \\
\hline $213-16-1,89-90 \mathrm{~cm}$ & & & $\mathrm{X}$ & \begin{tabular}{|l|l} 
\\
\end{tabular} & $\mathrm{X}$ & & & & & & & & $\mathrm{X}$ & & & $\mathrm{X}$ & & $\mathrm{X}$ & & $\mathrm{X}$ & & $\mathrm{X}$ & & & $\mathrm{X}$ \\
\hline $213-16-2,4-5 \mathrm{~cm}$ & $\mathrm{X}$ & & $\mathrm{X}$ & $\mathrm{X}$ & $\mathrm{X}$ & & & & & & & & \begin{tabular}{l|l}
$\mathrm{X}$ & 2 \\
\end{tabular} & $\mathrm{X}$ & & $\mathrm{X}$ & & $\mathrm{X}$ & & & & \begin{tabular}{l|l}
$\mathrm{X}$ & $\mathrm{Z}$ \\
\end{tabular} & $\mathrm{X}$ & & $\mathrm{X}$ \\
\hline $213-16-3,25-26 \mathrm{~cm}$ & & $\mathrm{x}$ & $\mathrm{X}$ & & $\mathrm{X}$ & & & & & & & & $\mathrm{X} / \mathrm{z}$ & $\mathrm{X}$ & & & & $\mathrm{X}$ & & & & $\mathrm{X}$ & & & $\mathrm{X}$ \\
\hline $213-16-4,18-19 \mathrm{~cm}$ & $\mathrm{X}$ & $\mathrm{x}$ & & \begin{tabular}{|l|l|l}
$\mathrm{X}$ & 3 \\
\end{tabular} & $\mathrm{X}$ & & & & & & & & \begin{tabular}{l|l}
$\mathrm{X}$ & $\mathrm{s}$ \\
\end{tabular} & $\mathrm{X}$ & & & \begin{tabular}{|l|l}
$\mathrm{X}$ & \\
\end{tabular} & $\mathrm{X}$ & & & & \begin{tabular}{l|l}
$\mathrm{X}$ & $\mathrm{X}$ \\
\end{tabular} & $\mathrm{X}$ & & $\mathrm{X}$ \\
\hline $213-16, \mathrm{CC}$ & & $\mathrm{X}$ & $\mathrm{X}$ & & & $\mathrm{X}$ & & & & & $\mathrm{X}$ & & \begin{tabular}{l|l}
$\mathrm{X}$ & $\mathrm{z}$ \\
\end{tabular} & $\mathrm{X}$ & & & & & & $\mathrm{X}$ & & & $\mathrm{X}$ & & $\mathrm{X}$ \\
\hline $213-17-1,120 \mathrm{~cm}$ & & $\mathrm{x}$ & $\mathrm{x}$ & & & & & $\mathrm{X}$ & & & & & & & & & \begin{tabular}{|l|l}
$\mathrm{X}$ \\
\end{tabular} & $\mathrm{X}$ & $\mathrm{X}$ & & & & $\mathrm{X}$ & & \\
\hline
\end{tabular}

Figure 3. Checklist of calcareous nannofossils recovered at Site 213.

meters during the subsequent 26 m.y. (see Berger, 1972), the approximate depth of the calcium carbonate compensation level at the time when calcareous sediments ceased to accumulate at these sites can be roughly estimated. Based on paleontological data, calcareous sediments accumulated at Site 213 for about 8 m.y. after initial formation of the crust and at Site 215 for about 11 m.y. Total sediment thickness at the two sites is the same, and it can probably be assumed, therefore, that the 300-meter difference in depth at the two sites reflects original irregularities of ridge elevation when they were formed. Thus, Site 215, which accumulated calcareous sediments for about 3 m.y. longer than Site 213 started out some 300 meters shallower than the latter site. If an average of 10 m.y. for the calcareous sediment accumulation period at the two sites (a most convenient figure, indeed) is assumed, then it follows that calcareous sediments ceased to accumulate when these sites dropped to a depth of about 3700 meters. Or, putting it another way, the regional calcium carbonate compensation depth was at a depth of about 3700 meters about 40 m.y. ago.

It is noteworthy that lower latitude pelagic sediments of this same age are characterized by siliceous sediments and by chert, especially in the Atlantic Ocean, a feature lacking at Site 213 and developed weakly at Site 215 . Although the above two sites are now in tropical latitudes, a more southerly latitude is implied for these sites in most reconstructions of the proto-Indian ocean.
Sites 214,216 , and 217 were all drilled along the crest of Ninetyeast Ridge. At all three of these sites presumably a complete section was penetrated, although continuous coring was done only at Site 214 . A nearly complete Tertiary zonal succession can be recognized at Site 214, and of the two zones not recognized, one, the mid-Pliocene Discoaster asymmetricus Zone, frequently is difficult to recognize elsewhere in pelagic sections. Moreover, the missing zone falls between two cores, and it is entirely possible that the interval containing this zone was lost during coring. The second zone not recognized at Site 214 is the mid-Oligocene Sphenolithus predistentus Zone. In this case the missing zone falls within a core, and its absence either represents a hiatus or inadequate development of the Sphenolithus lineage on which is based the recognition of this zone. At Site 216, and, to a lesser extent, Site 217, this zone is developed. Most of the zones not recognized at Sites 216 and 217 correspond to uncored intervals or to intervals where recovery was poor.

At each of the above three sites shoaling can be recognized as basement is approached. It appears that at the time of formation of the crust at these sites, the crest of Ninetyeast Ridge was at or near sea level. It is of interest, therefore, that members of the family Braarudosphaeradae are sparce in the early Tertiary sediments at Site 214 . At this site Paleocene and lower Eocene sediments were deposited in what is interpreted to be a lagoonal or shelf-like environment. Elsewhere, as in California (Sullivan, 
1964, 1965), sediments of this age and bathymetric range contain diverse assemblages of pentaliths, and the same is true of lower, middle, and upper Eocene sediments elsewhere (Bouché, 1962; Levin and Joerger, 1967; Bramlette and Sullivan, 1961; Bybell and Gartner, 1972). It may be significant that all of the lower Tertiary nannofloras with diverse pentalith assemblages are from regions which had a subtropical to temperate climate, while all of the Ninetyeast Ridge sites, including Site 214 , probably originated at relatively higher latitudes or were under the influence of high latitude oceanic conditions.

For Sites 216 and 217, no clear ecological inferences can be made from the oldest calcareous nannofossils above basement. It is unclear whether the low diversity recorded is due entirely to the scarcity of nannofossils in the samples, or whether it also is attributable to shallow water conditions or high latitude.

The nannofossils from Site 218 are precisely what might be expected in an open ocean area that receives a great deal of clastic sediment. The normal pelagic contribution is diluted by the clastic sediments being transported to the ocean floor by turbid flows and in suspension. Thus the abundance of nannofossils is related inversely to grain size and directly to carbonate content. In the case of Site 218, sufficient nannofossils were recovered to permit adequate biostratigraphic determinations.

\section{CRETACEOUS-TERTIARY BOUNDARY}

At Sites 216 and 217 on Ninetyeast Ridge the Cretaceous-Tertiary boundary was penetrated, and at Site 216 relatively undisturbed sediment was recovered across this boundary (Figure 10). The sediment above about $103 \mathrm{~cm}$ is uniform in texture, and color changes are gradational. Between 103 and $114 \mathrm{~cm}$ light buff to white chalk fragments, mottled and covered with green specks, float in a matrix of faintly and irregularly banded brownish gray chalk. Below about $107 \mathrm{~cm}$ the white chalk fragments lack the green specks, are irregular in size, and flattened horizontally. Below $130 \mathrm{~cm}$ the dark bands make up an even smaller proportion, and the white chalk fragments become more massive. Nannofossil assemblages from a selected sample in the vicinity of the Cretaceous-Tertiary boundary are as follows.

\section{2-216-23-2; $108 \mathrm{~cm}$; brownish-buff chalk}

Chiasmolithus danicus, Cruciplacolithus helis, Micula sp., Makalius reinhardti, Zygodiscus sigmoides, Cribrosphaerella sp., Markalius astroporus, numerous small and some medium-sized placoliths variously assigned to the genera Ericsonia, Biscutum, Marlkalius, Coccolithus. Predominantly Danian assemblage with some Maastrichtian contaminants.

\section{$109 \mathrm{~cm}$; dark layer in chalk}

Cuiciplacolithus helis, Markalius reinhardti, Zygodiscus sigmoides, Chiasmolithus danicus, Watznaueria barnesae, many small unidentifiable placolith as at $108 \mathrm{~cm}$. Predominantly Danian assemblage with some Maastrichtian contaminants.
$110 \mathrm{~cm}$; white chalk fragment covered with fine green layer, in brownish-buff chalk

Micula sp., Watznaueria barnesae, Arkhangelskiella cymbiformia, Cylindralithus gallicus, Lithraphidites quadratus, Cretarhabdus sp., Prediscosphaera cretacea, much unidentifiable debris. Maastrichtian assemblage.

\section{$117 \mathrm{~cm}$; dark layer in brownish-buff chalk}

Zygodiscus sigmoides, Chiasmolithus danicus, Micula sp., Lithraphidites quadratus, Cruciplacolithus helis, Arkhangelskiella cymbiformis, Markalius astroporus, Markalius reinhardti, Prediscosphaera cretacea, numerous small, unidentifiable placoliths. Predominantly Danian assemblage with some Maastrichtian contaminants.

\section{$139 \mathrm{~cm}$; white chalk in mottled interval}

Micula sp., Watznaueria barnesae, Lithraphidites quadratus, Arkhangelskiella cymbiforms, Nephrolithus frequens, Cretarhabdus sp., much unidentifiable debris. Late Maastrichtian assemblage.

The sediments above $103 \mathrm{~cm}$ consist largely of unidentifiable debris with predominantly Danian age nannofossils admixed with very few Maastrichtian specimens. The matrix and bands below $103 \mathrm{~cm}$ have a similar composition and age. The nannofossils indicate that the Danian age sediment at this site is not the oldest known Tertiary although it is early Danian (M.N. Bramlette, personal communication). The white chalk fragments below $103 \mathrm{~cm}$ also consist chiefly of unidentifiable debris and contain late Maastrichtian nannofossil assemblages, including Nephrolithus frequens and Cylindralithus gallicus. Thus, on the Ninetyeast Ridge, as seemingly everywhere in the marine realm, the youngest Cretaceous sediments are separated by a hiatus from the oldest Tertiary sediments.

Some novel and ingenious explanations have been offered for the widespread occurrence of this hiatus. In this particular instance the evidence seems to indicate that during the interval of nondeposition the chemistry of the ocean water in this region was such as to favor lithification of the late Maastrichtian sediments. It is obvious from the sedimentary structures in the core that the Maastrichtian sediments were relatively firm at the time when calcareous sediments again started to accumulate in early Danian time. Some solution of Maastrichtian chalk no doubt occurred during the interval represented by the hiatus, but the age of the highest Maastrichtian sediment indicates that relatively little material was lost. Indeed, most of the hiatus represents nondeposition rather than solution. According to Worsley's (1971) model of the terminal Cretaceous event the relatively short duration of noncarbonate deposition at Site 216 would require that the site be located at a relatively shallow depth. This seems to be borne out by the late Maastrichtian age of the oldest pelagic sediments above basement recovered at this site and the fact that immediately above basement the sediment indicates a lagoonal or shallow shelf environment. 


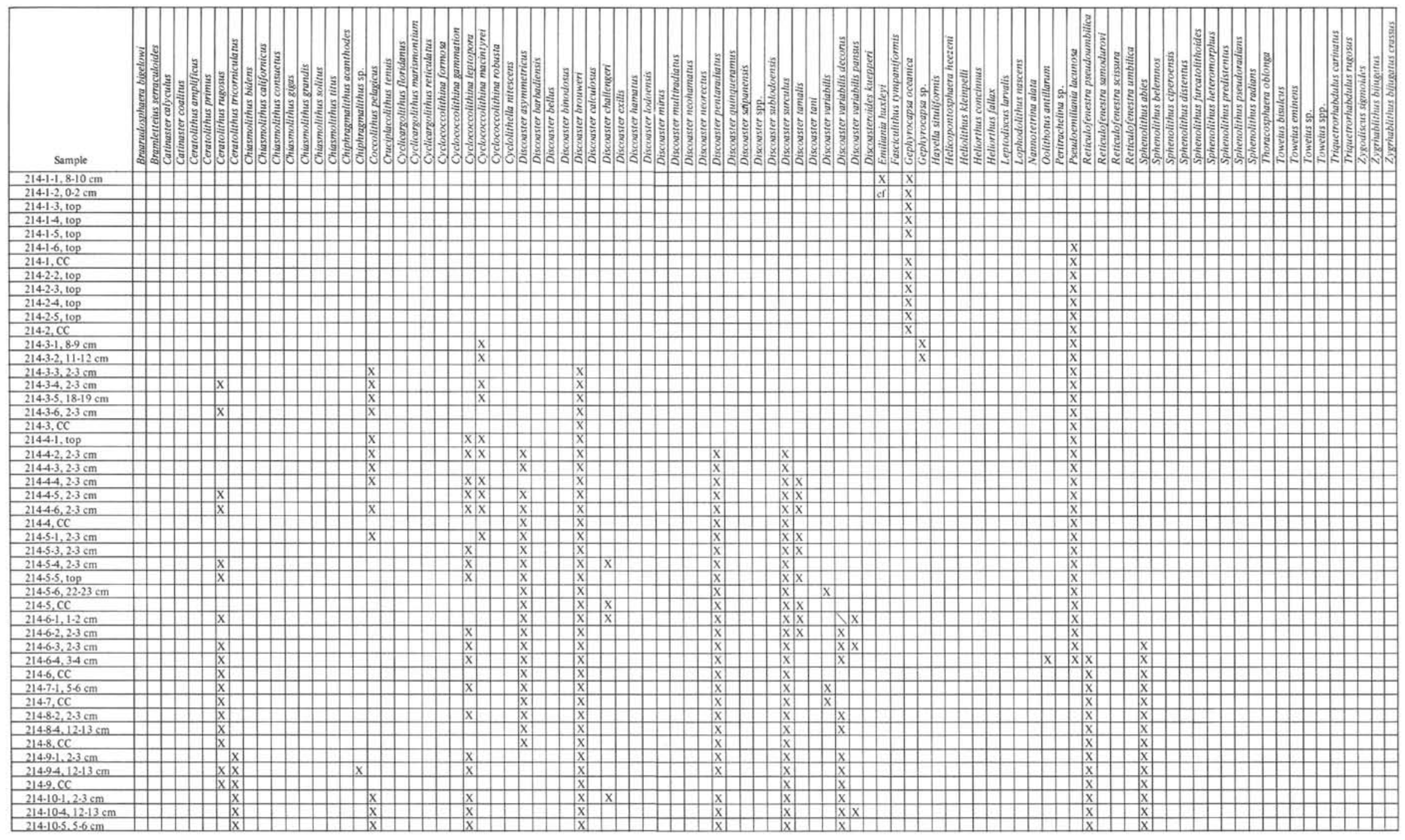

Figure 4. Checklist of calcareous nannofossils recovered at Site 214. 


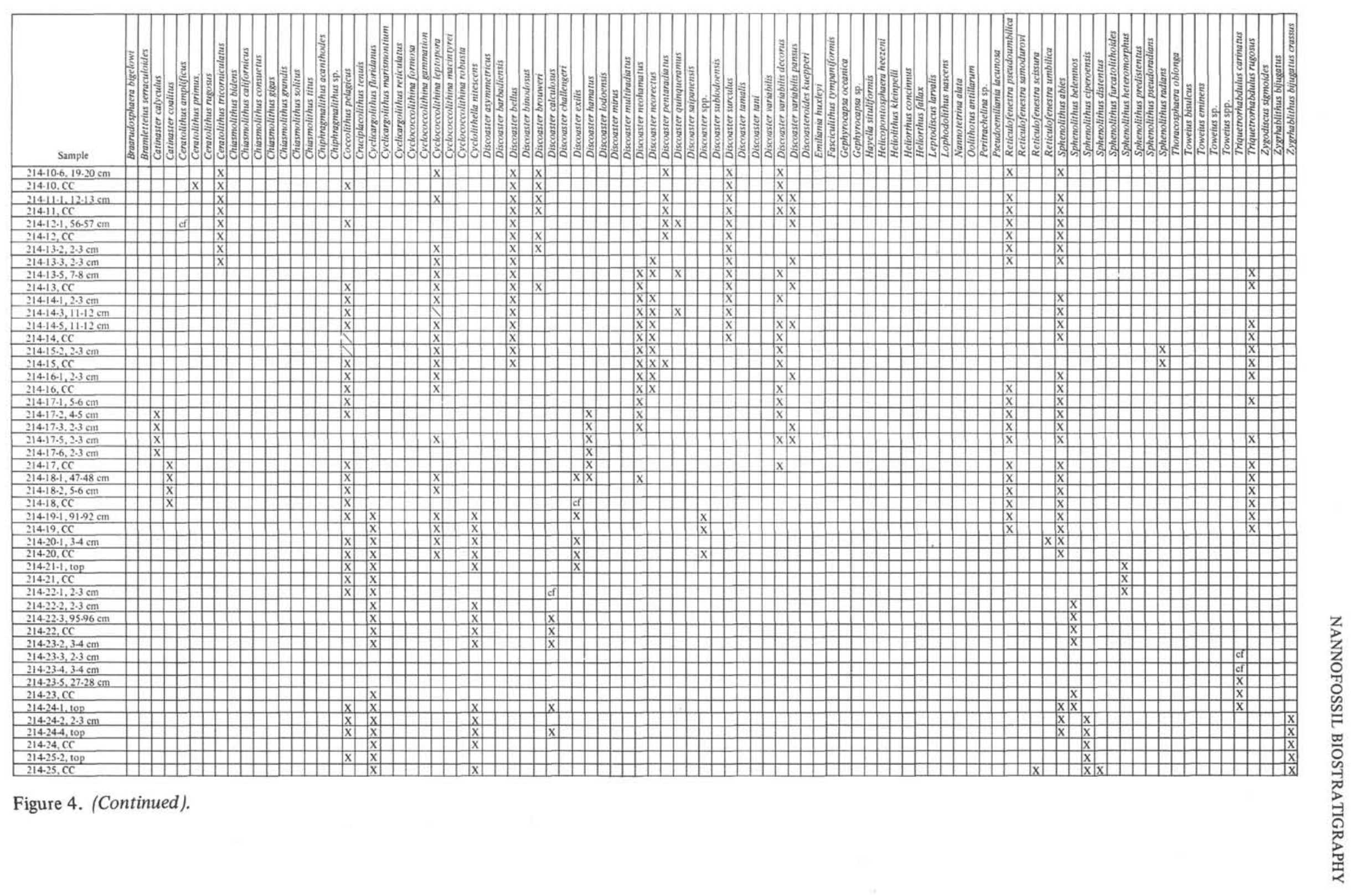




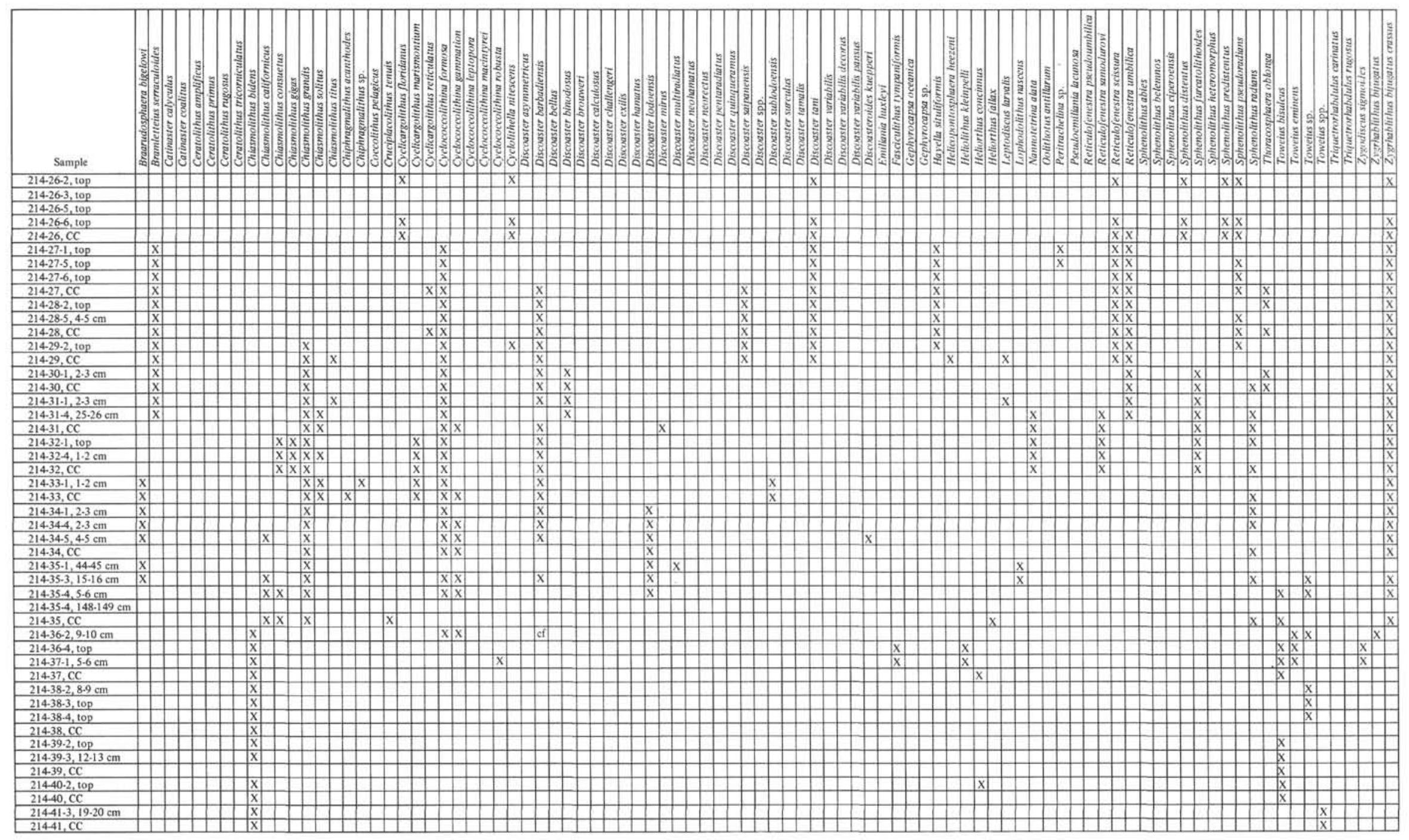

Figure 4. (Continued). 


\section{REFERENCES}

Berger, W. H., 1972. Deep sea carbonates: Dissolution facies and age-depth constancy: Nature, v. 236, p. 392395.

Bouché, P. M., 1962. Nannofossiles calcaires du Lutétian du bassin de Paris: Rev. Micropaleontologie, v. 5, p. 75-103.

Bramlette, M. N. and Sullivan, F. R., 1961. Coccolithophorids and related nannoplankton of the early Tertiary in California: Micropaleontology, v. 7, p. 129-188.

Bramlette, M. N., and Wicoxon, J. A., 1967. Middle tertiary calcareous nannoplankton of the Cipero section, Trinidad W. I.: Tulane Studies Geol., v. 5, p. 93-131.

Bukry, D., 1971. Cenozoic calcareous nannofossils from the Pacific Ocean: San Diego Soc. Nat. Hist. Trans., v. 16, p. 303-327.

, 1972. Further comments on coccolith stratigraphy, Leg 12, Deep Sea Drilling Project. In Laughton, A. S., Berggren, W. A., et al., Initial Reports of the Deep Sea Drilling Project, Volume XII: Washington (U. S. Government Printing Office), p. 1071-1083.

Bybell, L. and Gartner, S., 1972. Provincialism among mid-Eocene calcareous nannofossils: Micropaleontology, v. 18 , p. $319-336$.

Gartner, S., 1969. Correlation of Neogene planktonic foraminifer and calcareous nannofossil zones: Gulf Coast Assoc. Geol. Soc. Trans., v. 19, p. 585-599.

1971. Calcareous nannofossils from the JOIDES Blake Plateau cores, and revision of Paleogene nannofossil zonation: Tulane Studies Geol. Paleontol., v. 8, p. 101-121.

1973. Absolute chronology of the Late Neogene calcareous nannofossil succession in the Equatorial Pacific: Geol. Soc. Am. Bull., v. 84, p. 2021-2034.
Hay, W. W. and Mohler, H. P., 1967. Calcareous nannoplankton from early Tertiary rocks at Pont Labau, France, and Paleocene early Eocene correlations: J. Paleontol., v. 41, p. 1505-1541.

Hay, W. W., Mohler, H. P., Roth, H. P., Schmidt, R. R., and Boudreaux, J.E., 1967. Calcareous nannoplankton zonation of the Cenozoic of the Gulf Coast and Caribbean-Antillean area, and transoceanic correlation: Gulf Coast Assoc. Geol. Soc. Trans., v. 17, p. 428-480.

Levin, H. L. and Joerger, A. P., 1967. Calcareous nannoplankton from the Tertiary of Alabama: Micropaleontology, v. 13, p. 163-182.

Martini, E., 1970. Standard Paleogene calcareous nannoplankton zonation: Nature, v. 226, p. 560-561. , 1971. Standard Tertiary and Quaternary calcareous nannoplankton zonation: Plank. Conf., 2nd, Rome, 1970, Proc., p. 739-785.

Martini, E. and Worsley, T. T., 1970. Standard Neogene calcareous nannoplankton zonation: Nature, v. 225, p. 289-290.

Menard, H. W., 1969. Elevation and subsidence of oceanic crust: Earth Planet. Sci. Lett., v. 6, p. 275-284.

Roth, P. H., 1970. Oligocene calcareous nannoplankton biostratigraphy: Ecolog. Geol. Helv., v. 63, p. 799-881.

Sclater, J. G., Anderson, R. N., and Bell, M. L., 1971. The elevation of ridges and the evolution of the Central Eastern Pacific: J. Geophys. Res., v. 76, p. 7888.

Sullivan, F. R., 1964. Lower Tertiary nannoplankton from the California Coast Ranges-I Paleocene: Calif. Univ. Pubs. Geol. Sci., v. 53, p. 163-227.

, 1965. Lower Tertiary nannoplankton from the California Coast Ranges-II Eocene: Calif. Univ. Pubs. Geol. Sci., v. 53, p. 1-75.

Worsley, T. R., 1971. The terminal Cretaceous event: Nature, v. 230 , p. $318-320$.

Worsley, T. and Martini, E., 1970. Late Maastrichtian nannoplankton provinces: Nature, v. 225, p. 1242-1243. 


\begin{tabular}{|c|c|c|c|c|c|c|c|c|c|c|c|c|c|c|c|c|c|c|c|c|c|c|c|c|c|c|c|c|c|c|c|c|c|}
\hline Sample & 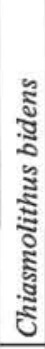 & 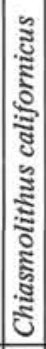 & 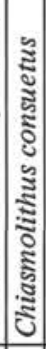 & 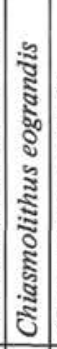 & 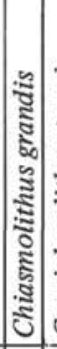 & 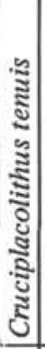 & 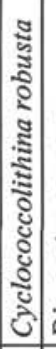 & 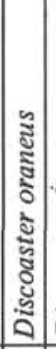 & 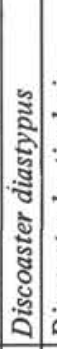 & 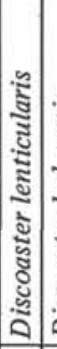 & 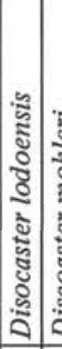 & 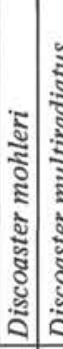 & 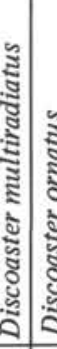 & 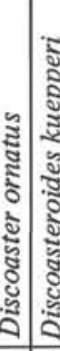 & 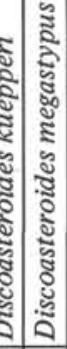 & 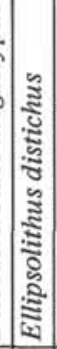 & 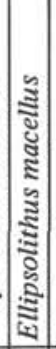 & 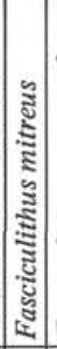 & 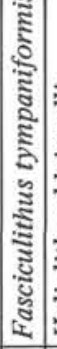 & 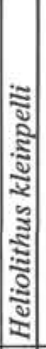 & 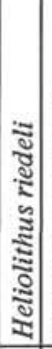 & 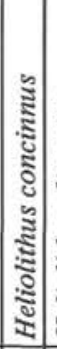 & 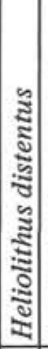 & 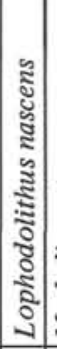 & 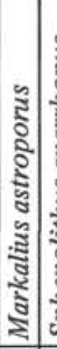 & 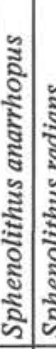 & 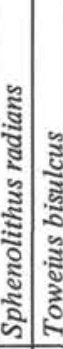 & 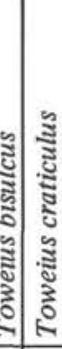 & 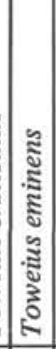 & 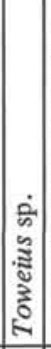 & 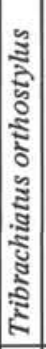 & 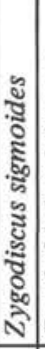 & 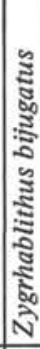 \\
\hline $215-9-3,130-131 \mathrm{~cm}$ & & & & & & & & & & & $\mathrm{X}$ & & $\mathrm{X}$ & $\mathrm{X}$ & $\mathrm{x}$ & & & & & & & & & & & & $\mathrm{X}$ & & & & $\mathrm{x}$ & & \\
\hline $215, \mathrm{CC}$ & & & & & $\mathrm{x}$ & & & & & & $\mathrm{X}$ & & & $\mathrm{X}$ & $\mathrm{X}$ & & & & & & & & & & & & $\mathrm{x}$ & & & & $\mathrm{X}$ & & \\
\hline $215-10-1,104-105 \mathrm{~cm}$ & $\mathrm{X}$ & & $\mathrm{X}$ & & $\mathrm{x}$ & & & & $\mathrm{X}$ & & & & \begin{tabular}{l|l}
$\mathrm{X}$ & $\mathrm{X}$ \\
\end{tabular} & \begin{tabular}{l|l}
$x$ & $X$ \\
\end{tabular} & $\mathrm{X}$ & & $\mathrm{x}$ & & & & & & & & & & $\mathrm{X}$ & $\mathrm{X}$ & & & $\mathrm{X}$ & & \\
\hline $215-10-2,30-33 \mathrm{~cm}$ & $\mathrm{X}$ & & $\mathrm{X}$ & $\mathrm{X}$ & $\mathrm{X}$ & & & $\mathrm{X}$ & $\mathrm{X}$ & & & & $\mathrm{X}$ & & $\mathrm{X}$ & & & & & & & & & & & & $\mathrm{X}$ & & & & $\mathrm{X}$ & & \\
\hline $215-10-3,42-43 \mathrm{~cm}$ & $\mathrm{X}$ & & $\mathrm{x}$ & $\mathrm{X}$ & & & & & $\mathrm{X}$ & $\mathrm{X}$ & & & $\mathrm{X}$ & & $\mathrm{X}$ & & & & $\mathrm{X}$ & & & & & & & & & & & $\mathrm{x}$ & & & \\
\hline $215-10-3,105-106 \mathrm{~cm}$ & & & & $\mathrm{X}$ & & & & & $\mathrm{X}$ & & & & & & & & & & & & & & & & & & & & & & & & \\
\hline $215-10, \mathrm{CC}$ & $\mathrm{X}$ & & $\mathrm{x}$ & $\mathrm{X}$ & & & & & & $\mathrm{X}$ & & & $\mathrm{X} \mid \mathrm{X}$ & $\mathrm{X}$ & $\mathrm{X}$ & $\mathrm{x}$ & $\mathrm{X}$ & & $\mathrm{X}$ & & & & $\mathrm{x}$ & $\mathrm{X}$ & & & & $\mathrm{X}$ & & $\mathrm{x}$ & & $\mathrm{X}$ & \\
\hline $215-11-1,30-31 \mathrm{~cm}$ & $\mathrm{X}$ & & $\mathrm{x}$ & $\mathrm{X}$ & & & & & $\mathrm{X}$ & & & \begin{tabular}{l|l}
$\mathrm{cf}$ & $\mathrm{X}$ \\
\end{tabular} & $\mathrm{X}$ & & $\mathrm{X}$ & $\mathrm{x}$ & $\mathrm{x}$ & & $\mathrm{X}$ & & & & & $\mathrm{X}$ & & & & $\mathrm{X}$ & & & & $\mathrm{X}$ & $\mathrm{X}$ \\
\hline $215-11-2,4-5 \mathrm{~cm}$ & & & & $\mathrm{X}$ & & & & & $\mathrm{X}$ & & & & & & & & & & & & & & & & & & & & & & & & \\
\hline $215-11-2,80-81 \mathrm{~cm}$ & & & & $\mathrm{X}$ & & & & & $\mathrm{X}$ & & & & & & & & & & & & & & & & & & & & & & & & \\
\hline $215-11-3,2-3 \mathrm{~cm}$ & & & & $\mathrm{X}$ & & & & & & & & & & & & & & & & & & & & & & & & & & & & & \\
\hline $215-11-3,89-90 \mathrm{~cm}$ & $\mathrm{X}$ & & & & & & & & & $\mathrm{X}$ & & \begin{tabular}{l|l}
$\mathrm{X}$ & $\mathrm{X}$ \\
\end{tabular} & $\mathrm{X}$ & & $\mathrm{X}$ & $\mathrm{x}$ & & & $\mathrm{X}$ & & & & & & & & & $\mathrm{X}$ & $\mathrm{x}$ & & & $\mathrm{X}$ & \\
\hline $215-11, \mathrm{CC}$ & $\mathrm{X}$ & & $\mathrm{X}$ & & & & & & & $\mathrm{x}$ & & \begin{tabular}{l|l}
$\mathrm{X}$ & $\mathrm{x}$ \\
\end{tabular} & $\mathrm{X}$ & & $\mathrm{X}$ & & & & $\mathrm{X}$ & & & & & & & & & $\mathrm{X}$ & $\mathrm{x}$ & & & $\mathrm{X}$ & \\
\hline $215-12-1,19-20 \mathrm{~cm}$ & $\mathrm{X}$ & & $\mathrm{x}$ & & & & & & & $\mathrm{X}$ & & \begin{tabular}{l|l}
$\mathrm{X}$ & $\mathrm{X}$ \\
\end{tabular} & $\mathrm{X}$ & & & & & $\mathrm{X}$ & $\mathrm{X}$ & & & & & & & & & & $\mathrm{X}$ & & & & \\
\hline $215-12, \mathrm{CC}$ & $\mathrm{X}$ & & $\mathrm{X}$ & & & & & & & $\mathrm{X}$ & & & $\mathrm{X}$ & & & $\mathrm{x}$ & & $\mathrm{X}$ & $\mathrm{X}$ & & & & & & & & $\mathrm{X}$ & $\mathrm{X}$ & $\mathrm{x}$ & & & & \\
\hline $215-13-2,4-5 \mathrm{~cm}$ & $\mathrm{X}$ & $\mathrm{X}$ & & & & & $\mathrm{X}$ & & & $\mathrm{X}$ & & \begin{tabular}{l|l}
$\mathrm{X}$ & $\mathrm{x}$ \\
\end{tabular} & $\mathrm{X}$ & & & $\mathrm{x}$ & $\mathrm{x}$ & $\mathrm{x}$ & $\mathrm{X}$ & & & & & & & & & $\mathrm{x}$ & $\mathrm{X}$ & & & $\mathrm{X}$ & \\
\hline $215-13-2,97-98 \mathrm{~cm}$ & $\mathrm{X}$ & $\mathrm{x}$ & & & & & $\mathrm{X}$ & & & & & $\mathrm{x}$ & & & & & $\mathrm{x}$ & & $\mathrm{x}$ & $\mathrm{x}$ & & & & & & $\mathrm{X}$ & $\mathrm{X}$ & $\mathrm{X}$ & $\mathrm{x}$ & & & & \\
\hline $215-13-3,90-91 \mathrm{~cm}$ & $\mathrm{X}$ & $\mathrm{X}$ & & & & & $\mathrm{X}$ & & & & & $\mathrm{X}$ & & & & & $\mathrm{X}$ & $\mathrm{x}$ & $\mathrm{X}$ & & & & & & & & $\mathrm{X}$ & $\mathrm{x}$ & $\mathrm{X}$ & & & & \\
\hline $215-13, \mathrm{CC}$ & $\mathrm{X}$ & $\mathrm{X}$ & & & & $\mathrm{X}$ & $\mathrm{X}$ & & & & & $\mathrm{X}$ & & & & & $\mathrm{x}$ & & $\mathrm{X}$ & & & & & & & $\mathrm{X}$ & $\mathrm{X}$ & $\mathrm{X}$ & $\mathrm{X}$ & & & $\mathrm{X}$ & \\
\hline $215-14-1,12-13 \mathrm{~cm}$ & $\mathrm{X}$ & & $\mathrm{x}$ & & & & $\mathrm{X}$ & & & & & $\mathrm{X}$ & & & & & & & $\mathrm{X}$ & & $\mathrm{X}$ & & & & & $\mathrm{X}$ & & $\mathrm{X}$ & $\mathrm{x}$ & & & $\mathrm{X}$ & \\
\hline $215-14-4,2-3 \mathrm{~cm}$ & $\mathrm{X}$ & & & & & $\mathrm{X}$ & & & & & & $\mathrm{x}$ & & & & & & & $\mathrm{X}$ & & & & & & & & & $\mathrm{X}$ & $\mathrm{x}$ & & & $\mathrm{X}$ & \\
\hline $215-14-4,91-92 \mathrm{~cm}$ & $\mathrm{X}$ & & & & & & & & & & & $\mathrm{X}$ & & & & & & & $\mathrm{X}$ & & $\mathrm{X}$ & & & & & & & & $\mathrm{X}$ & & & $\mathrm{X}$ & \\
\hline $215-14-5,2-3 \mathrm{~cm}$ & $\mathrm{X}$ & & & & & $\mathrm{X}$ & & & & & & $\mathrm{X}$ & & & & & & & $\mathrm{X}$ & $\mathrm{x}$ & & & & & & & & & $\mathrm{X}$ & & & $\mathrm{X}$ & \\
\hline $215-14-5,90-91 \mathrm{~cm}$ & $\mathrm{X}$ & & & & & & & & & & & $\mathrm{X}$ & & & & & & & $\mathrm{x}$ & $\mathrm{x}$ & $\mathrm{X}$ & & & & & & & $\mathrm{X}$ & $\mathrm{x}$ & & & $\mathrm{X}$ & \\
\hline $215-14, \mathrm{CC}$ & $\mathrm{X}$ & & $\mathrm{x}$ & & & & $\mathrm{X}$ & & & & & $\mathrm{x}$ & & & & & & & $\mathrm{x}$ & $\mathrm{X}$ & & & & & & & & & $\mathrm{X}$ & & & $\mathrm{X}$ & \\
\hline $215-15-1,112-113 \mathrm{~cm}$ & $\mathrm{X}$ & & $\mathrm{x}$ & & & & & & & & & & & & & & & & $\mathrm{x}$ & $\mathrm{x}$ & & & & & & & & $\mathrm{X}$ & $\mathrm{X}$ & & & $\mathrm{X}$ & \\
\hline $215-15-4,20-21 \mathrm{~cm}$ & $\mathrm{X}$ & & & & & & & & & & & & & & & & & & $\mathrm{X}$ & $\mathrm{x}$ & & & & & & & & & $\mathrm{X}$ & & & $\mathrm{X}$ & \\
\hline $215-15, \mathrm{CC}$ & $\mathrm{X}$ & $\mathrm{X}$ & $\mathrm{x}$ & & & & & & & & & & & & & & & & $\mathrm{X}$ & $\mathrm{x}$ & & & & & & & & $\mathrm{X}$ & $\mathrm{x}$ & & & $\mathrm{X}$ & \\
\hline $215-16-1,99-100 \mathrm{~cm}$ & $\mathrm{X}$ & $\mathrm{X}$ & & & & $\mathrm{X}$ & & & & & & & & & & & & & $\mathrm{X}$ & & $\mathrm{X}$ & & & & & & & $\mathrm{X}$ & $\mathrm{x}$ & & & $\mathrm{X}$ & \\
\hline $215-16-4,2-3 \mathrm{~cm}$ & $\mathrm{X}$ & & & & & $\mathrm{X}$ & $\mathrm{X}$ & & & & & & & & & & & & $\mathrm{X}$ & & $\mathrm{X}$ & & & & & & & $\mathrm{X}$ & $\mathrm{x}$ & & & $\mathrm{X}$ & \\
\hline $215-16-4,90-91 \mathrm{~cm}$ & $\mathrm{X}$ & & & & & $\mathrm{x}$ & $\mathrm{X}$ & & & & & & & & & & & & $\mathrm{X}$ & $\mathrm{x}$ & $\mathrm{X}$ & & & & & & & $\mathrm{X}$ & $\mathrm{x}$ & & & $\mathrm{X}$ & \\
\hline $215-16, \mathrm{CC}$ & $\mathrm{X}$ & & & & & $\mathrm{X}$ & $\mathrm{X}$ & & & & & & & & & & & & $\mathrm{X}$ & & $\mathrm{x}$ & $\mathrm{X}$ & & & & & & $\mathrm{X}$ & & & & $\mathrm{X}$ & \\
\hline $215-17-1,90 \mathrm{~cm}$ & $\mathrm{X}$ & & & & & $\mathrm{x}$ & $\mathrm{X}$ & & & & & & & & & & & & $\mathrm{x}$ & $\mathrm{x}$ & & & & & $\mathrm{X}$ & & $\mathrm{X}$ & $\mathrm{x}$ & & & & $\mathrm{x}$ & \\
\hline $215-17-1,106 \mathrm{~cm}$ & $\mathrm{X}$ & & & & & $\mathrm{x}$ & $\mathrm{X}$ & & & & & & & & & & & & $\mathrm{X}$ & & & & & & & & $\mathrm{X}$ & $\mathrm{X}$ & & & & $\mathrm{X}$ & \\
\hline $215-17-1,110 \mathrm{~cm}$ & $\mathrm{X}$ & $\mathrm{X}$ & & & & $\mathrm{X}$ & $\mathrm{X}$ & & & & & & & & & & & & $\mathrm{X}$ & & & & & & & & $\mathrm{X}$ & $\mathrm{X}$ & & & & $\mathrm{X}$ & \\
\hline $215-17, \mathrm{CC}$ & $\mathrm{X}$ & & & & & & & & & & & & & & & & & & $\mathrm{X}$ & & & & & & & & $\mathrm{X}$ & $\mathrm{X}$ & & & & $\mathrm{X}$ & \\
\hline
\end{tabular}

Figure 5. Checklist of calcareous nannofossils recovered at Site 215. 


\begin{tabular}{|c|c|c|c|c|c|c|c|c|c|c|c|c|c|c|c|c|c|c|c|c|c|c|c|c|c|c|c|c|c|c|}
\hline Sample & 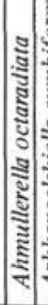 & 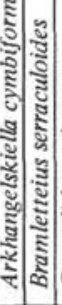 & 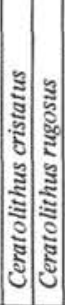 & 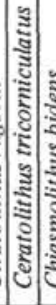 & 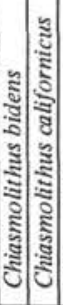 & 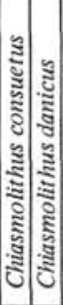 & 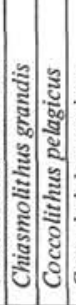 & 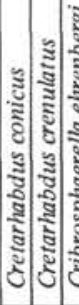 & 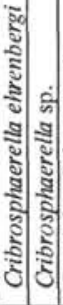 & 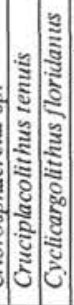 & 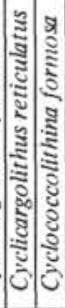 & 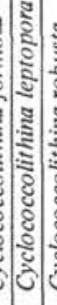 & 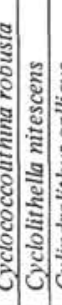 & 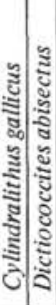 & : & 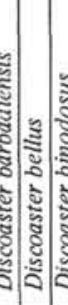 & 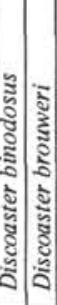 & 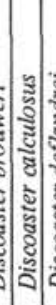 & 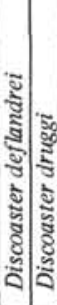 & : & 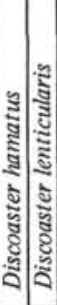 & $\begin{array}{l}\mid \\
\vdots \\
\vdots \\
\vdots\end{array}$ & : & : & 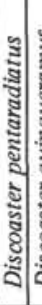 & : & 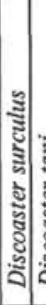 & : & & 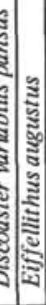 \\
\hline $216 \cdot 1 \cdot 1,2.3 \mathrm{~cm}$ & & & & & & & & & & & & $\mathrm{x}$ & & & & & & & & & & & & & & & & & & \\
\hline $216-1 \cdot 2$, top & & & & & & & & & & & & & & & & & & & & & & & & & & & & & & \\
\hline $216 \cdot 1 \cdot 3,4.5 \mathrm{~cm}$ & & & $\mathrm{x}$ & & & & & & & & & & & & & & & & & & & & & & & & & & & \\
\hline $216 \cdot 1 \cdot 4,3 \cdot 4 \mathrm{~cm}$ & & & & & & & & & & & & & & & & & & & & & & & & & & & & & & \\
\hline $216 \cdot 1 \cdot 6,3-4 \mathrm{~cm}$ & & & $\mathrm{x}$ & & & & & & & & & & & & & & & & & & & & & & & & & & & \\
\hline $216 \cdot 1, \mathrm{CC}$ & & & & & & & & & & & & $x$ & & & & & & & & & & & & & & & & & & \\
\hline $216 \cdot 2 \cdot 1,4-5 \mathrm{~cm}$ & & & $\mathrm{x}$ & & & & & & & & & & & & $\mathrm{x}$ & & $\mathrm{X}$ & & & & & & & & $\mathrm{X}$ & & & $\mathrm{X}$ & & \\
\hline $216-2-4$, top & & & $\mathrm{x}$ & & & & & & & & & $x$ & & & & & $\mathrm{X}$ & & & & & & & & & & & & & \\
\hline $216-2.5,21.22 \mathrm{~cm}$ & & & & & & & & & & & & & & & & & & & & & & & & & & & & & & \\
\hline $216 \cdot 2, \mathrm{CC}$ & & & $\mathrm{x}$ & & & & & & & & & $x$ & & & $x$ & & $\mathrm{x}$ & & & & & & & & $\mathrm{X}$ & & $\mathrm{x}$ & $\mathrm{x}$ & & \\
\hline $216 \cdot 3 \cdot 1,91.92 \mathrm{~cm}$ & & & & $\mathrm{x}$ & & & & & & & & 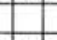 & & & & $\mathrm{X}$ & $\mathrm{x}$ & & & & & & & & 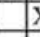 & $x$ & $\mathrm{x}$ & - & & \\
\hline $216 \cdot 3, \mathrm{CC}$ & & & & $x$ & & & $\mathrm{x}$ & & & & & $x$ & & & & $\mathrm{x}$ & $\mathrm{x}$ & & & & & & & & $\lambda$ & $x$ & & & & \\
\hline $216-4-1,2.3 \mathrm{~cm}$ & & & & & & & & & & & & $x$ & & & & & & & & & $\mathrm{X}$ & & & $\mathrm{x}$ & & & & $x$ & $\mathrm{X}$ & $x$ \\
\hline $216-4-2,4-5 \mathrm{~cm}$ & & & & & & & $\mathrm{x}$ & & & & & $\mathrm{x}$ & & & & & & & & $\mathrm{x}$ & & & & & & & & $\mathrm{X}$ & $\mathrm{X}$ & \\
\hline $216-4-3.2 .3 \mathrm{~cm}$ & & & & & & & & & & & & $\mathrm{x}$ & & & & & & & & $\mathrm{x}$ & & & & & & & & $x$ & & \\
\hline $216.4, \mathrm{CC}$ & & & & & & & $\mathrm{x}$ & & & & & $\mathrm{x}$ & & & & & & & & $\mathrm{X}$ & & & & & & & & & & \\
\hline $216 \cdot 5 \cdot 1,104 \cdot 105 \mathrm{~cm}$ & & & & & & & & & & $\mathrm{x}$ & & & $x$ & & & & & & & & & & & & & & & & & \\
\hline $216-5 \cdot 2,1.2 \mathrm{~cm}$ & & & & & & & & & & $\mathrm{X}$ & & & $\mathrm{x}$ & & & & & & & & & & & & & & & & & \\
\hline $216 \cdot 5 \cdot 3,2.3 \mathrm{~cm}$ & & & & & & & & & & $\mathrm{x}$ & & 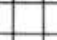 & $\mathrm{X}$ & & & & & & & & & & & & & & & & & \\
\hline $216 \cdot 5 \cdot 4$, top & & & & & & & & & & $\mathrm{x}$ & & & $\mathrm{x}$ & & & & & $\mathrm{X}$ & & & & & & & & & & & & \\
\hline $216.5, \mathrm{CC}$ & & & & & & & & & & $\mathrm{x}$ & & $\mathrm{x}$ & $\mathrm{x}$ & & & & & $\mathrm{x}$ & & & & & & & & & & & & \\
\hline $216 \cdot 6 \cdot 1,2 \cdot 3 \mathrm{~cm}$ & & & & & & & $\mathrm{x}$ & & & $\mathrm{x}$ & & & & & & & & & & & & & & & & & & & & \\
\hline $216 \cdot 6 \cdot 3,2 \cdot 3 \mathrm{~cm}$ & & & & & & & $\mathrm{x}$ & & & $\mathrm{x}$ & & & $\mathrm{x}$ & & & & & & & & & & & & & & & & & \\
\hline $216 \cdot 6, \mathrm{CC}$ & & & & & & & $x$ & & & $\mathrm{x}$ & & & $\mathrm{x}$ & & & & & $\mathrm{x}$ & $\mathrm{X}$ & & & & & & & & & & & \\
\hline $216 \cdot 7 \cdot 1,31.32 \mathrm{~cm}$ & & & & & & & $x$ & & & $\mathrm{x}$ & & & $\mathrm{x}$ & & & & & & & & & & & & & & & & & \\
\hline $216 \cdot 7, \mathrm{CC}$ & & & & & & & $x$ & & & $x$ & & & $\mathrm{x}$ & & & & & & $x$ & & & & & & & & & & & \\
\hline $216.8-1,91.92 \mathrm{~cm}$ & & & & & & & $\mathrm{x}$ & & & $\mathrm{x}$ & & & $\mathrm{x}$ & & & & & $\mathrm{X}$ & & & & & & & & & & & & \\
\hline $216 \cdot 8, \mathrm{CC}$ & & & & & & & $\mathrm{x}$ & & & $\mathrm{x}$ & & & & & & & & & $\mathrm{X}$ & & & & & & & & & & & \\
\hline $216.9 .1,13.14 \mathrm{~cm}$ & & & & & & & & & & $\mathrm{x}$ & & & $x$ & & & & & & & & & & & & & & & & & \\
\hline $216-9, \mathrm{CC}$ & & & & & & & & & & $\mathrm{x}$ & & & & & & & & & & & & & & & & & & & & \\
\hline $216 \cdot 10, \mathrm{CC}$ & & & & & & & $\mathrm{X}$ & & & $\mathrm{X}$ & & & $\mathrm{x}$ & $\mathrm{X}$ & & & & & & & & & & & & & & & & \\
\hline $216-11, \mathrm{CC}$ & & & & & & & $\mathrm{x}$ & & & $\mathrm{x}$ & & & & $\mathrm{x}$ & & & & & & & & & & & & & & & & \\
\hline $216.12 \cdot 1,74.75 \mathrm{~cm}$ & & & & & & & & & & $\mathrm{x}$ & & & & $\mathrm{x}$ & & & & & & & & & & & & & & & & \\
\hline $216 \cdot 12, \mathrm{CC}$ & & & & & & & & & & $\mathrm{X}$ & & & & $\mathrm{X}$ & & & & & & & & & & & & & & & & \\
\hline $216-13-1,108-109 \mathrm{~cm}$ & & & & & & & & & & $\mathrm{x}$ & & & & & & & & & & & & & & & & & & $\mathrm{X}$ & & \\
\hline $216.13, \mathrm{CC}$ & & & & & & & & & & $\mathrm{x}$ & & & $\mathrm{x}$ & & & & & & & & & & & & & & & $\mathrm{X}$ & & \\
\hline $216-14.1,97.98 \mathrm{~cm}$ & & & & & & & & & & $\mathrm{x}$ & & & & & & & & & & & & & & & & & & $x$ & & \\
\hline $216-14, \mathrm{CC}$ & & & & & & & & & & $x$ & & & & & & & & & & & & & & & & & & $\mathrm{X}$ & & \\
\hline $216-15 \cdot 1,80-81 \mathrm{~cm}$ & & $\mathrm{X}$ & & & & & & & & & & & & & & & & & & & & & & & & & & $x \mid$ & & \\
\hline
\end{tabular}

Figure 6. Checklist of calcareous nannofossils recovered at Site 216. 


\begin{tabular}{|c|c|c|c|c|c|c|c|c|c|c|c|c|c|c|c|c|c|c|c|c|c|c|c|c|c|c|c|c|c|c|}
\hline Sample & $\mid$ & 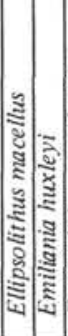 & 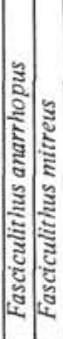 & 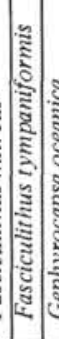 & 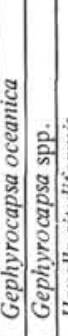 & 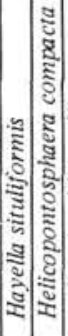 & 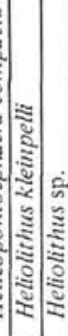 & 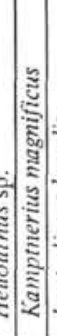 & 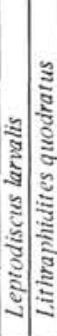 & : & 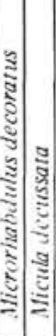 & 童 & 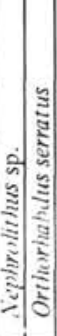 & 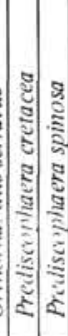 & 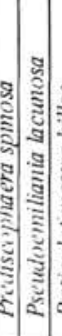 & 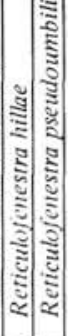 & 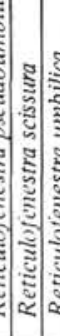 & 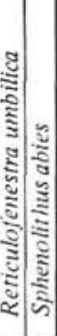 & 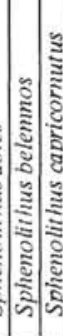 & 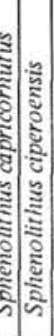 & 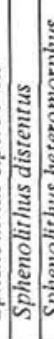 & & 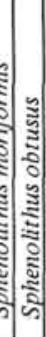 & 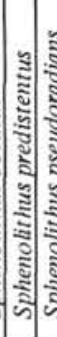 & 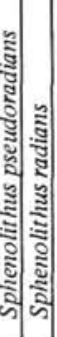 & : & 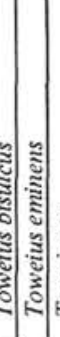 & & 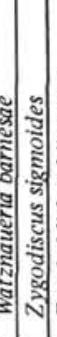 & 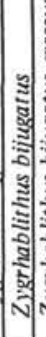 \\
\hline $216-1-1,2-3 \mathrm{~cm}$ & & $x$ & & & $x$ & & & & & & & & & & & & & & & & & & & & & & & & & \\
\hline $216 \cdot 1 \cdot 2$, top & & $\mathrm{x}$ & & & $\mathrm{x}$ & & & & & & & & & & & & & & & & & & & & & & & & & \\
\hline $216-1-3,4-5 \mathrm{~cm}$ & & $\mathrm{cf}$ & & & $\mathrm{x}$ & & & & & & & & & & & & & & & & & & & & & & & & & \\
\hline $216 \cdot 1-4,3 \cdot 4 \mathrm{~cm}$ & & & & & \begin{tabular}{l|l|}
$\mathrm{x}$ & $\mathrm{x}$ \\
\end{tabular} & & & & & & & & & & & & & & & & & & & & & & & & & \\
\hline $216-1 \cdot 6,3-4 \mathrm{~cm}$ & & & & & $\mathrm{x} \mid \mathrm{x}$ & & & & & & & & & & & & & & & & & & & & & & & & & \\
\hline $216 \cdot 1, \mathrm{CC}$ & & & & & $|x|$ & & & & & & & & & & $\mathrm{x}$ & & & & & & & & & & & & & & & \\
\hline $216-2-1,4-5 \mathrm{~cm}$ & & & & & & & & & & & & & & & $\mathrm{x}$ & & & $x$ & & & & & & & & & & & & \\
\hline $216 \cdot 2-4$, top & & & & & & & & & & & & & & & $\mathrm{cf}$ & & & $x$ & & & & & & & & & & & & \\
\hline $216-2.5,21-22 \mathrm{~cm}$ & & & & & & & & & & & & & & & cf & $\mathrm{X}$ & & $\mathrm{X}$ & & & & & & & & & & & & \\
\hline $216-2, \mathrm{CC}$ & & & & & & & & & & & & & & & & $\mathrm{X}$ & & $\mathrm{x}$ & & & & & & & & & & & & \\
\hline $216-3-1,91.92 \mathrm{~cm}$ & & & & & & & & & & & & & & & & $\mathrm{x}$ & & $x$ & & & & & & & & & & & & \\
\hline $216-3, \mathrm{CC}$ & & & & & & & & & & & & & & & & $\mathrm{x}$ & & $\mathrm{x}$ & & & & & & & & & & & & \\
\hline $216-4-1,2-3 \mathrm{~cm}$ & & & & & & & & & & & & & & & & $\mathrm{x}$ & & & & & & & & & & & & & & \\
\hline $216-4-2,4-5 \mathrm{~cm}$ & & & & & & & & & & & & & & & & $\mathrm{x}$ & & $\mathrm{x}$ & & & & & & & & & & & & \\
\hline $216-4-3,2-3 \mathrm{~cm}$ & & & & & & & & & & & & & & & & $\mathrm{x}$ & & $\mathrm{X}$ & & & & & & & & & & & & \\
\hline $216 \cdot 4, \mathrm{CC}$ & & & & & & & & & & & & & & & & $\mathrm{x}$ & & & & & & & & & & & & & & \\
\hline $216-5 \cdot 1,104-105 \mathrm{~cm}$ & & & & & & & & & & & & & & & & & & & & & & \begin{tabular}{l|l}
$x$ & $x$ \\
\end{tabular} & & & & & & & & \\
\hline $216-5.2,1-2 \mathrm{~cm}$ & & & & & & & & & & & & & & & & & & $\mathrm{x}$ & $x$ & & & $x$ & & & & & & & & \\
\hline $216 \cdot 5 \cdot 3,2 \cdot 3 \mathrm{~cm}$ & & & & & & & & & & & & & & & & & & & $\mathrm{x}$ & & & $\mathrm{x}$ & & & & & & & & \\
\hline $216-5-4$, top & & & & & & & & & & & & & & & & & & & & & & $\mathrm{X}$ & & & & & & & & \\
\hline $216-5, \mathrm{CC}$ & & & & & & & & & & & & & $\mathrm{x}$ & & & & & & & & & $\mathrm{x}$ & & & & & & & & \\
\hline $216-6-1,2-3 \mathrm{~cm}$ & & & & & & & & & & & & & & & & & & $\mathrm{x}$ & & & & $\mathrm{X}$ & & & & & & & & \\
\hline $216-6-3,2-3 \mathrm{~cm}$ & & & & & & & & & & & & & & & & & & $x$ & & & & $\mathrm{X}$ & & & & & & & & \\
\hline $216 \cdot 6, \mathrm{CC}$ & & & & & & & & & & & & & & & & & & $\mathrm{X}$ & & & & $? \mathrm{x}$ & & & & & & & & \\
\hline $216-7.1,31-32 \mathrm{~cm}$ & & & & & & & & & & & & & & & & & & $\mathrm{x}$ & $\mathrm{x}$ & $\mathrm{x}$ & & & & & & & & & & \\
\hline $216 \cdot 7, \mathrm{CC}$ & & & & & & & & & & & & & & & & & & $\mathrm{x}$ & & & & - & & & & & & & & 1 \\
\hline $216-8-1,91.92 \mathrm{~cm}$ & & & & & & & & & & & & & & & & & $\mathrm{x}$ & $x$ & & & & $\mathrm{X}$ & & & & & & & & \\
\hline $216 \cdot 8, \mathrm{CC}$ & & & & & & & & & & & & & & & & & & $\mathrm{x}$ & $\mathrm{x}$ & $\mathrm{x}$ & & $? \mathrm{x}$ & & & & & & & & \\
\hline $216-9-1,13.14 \mathrm{~cm}$ & & & & & & & & & & & & & & & & & & $x$ & & $\mathrm{x}$ & & & & & & & & & & \\
\hline $216-9, \mathrm{CC}$ & & & & & & & & & & & & & & & & & $\mathrm{X}$ & & & $\mathrm{x}$ & & & & & & & & & & \\
\hline $216.10, \mathrm{CC}$ & & & & & & & & & & & & & & & & & $\mathrm{x}$ & $\mathrm{x}$ & & $\mathrm{x}$ & & & & & & & & & & \\
\hline $216-11, \mathrm{CC}$ & & & & & & & & & & & & & & & & & $x$ & & & $x$ & $x$ & & & & & & & & & \\
\hline $216-12-1,74-75 \mathrm{~cm}$ & & & & & & & & & & & & & & & & & $\mathrm{x}$ & & & $\mathrm{x}$ & & & & & & & & & & \\
\hline $216 \cdot 12, \mathrm{CC}$ & & & & & & & & & & & & & & & & & $\mathrm{x}$ & & & $\mathrm{x}$ & $x$ & & & & & & & & & \\
\hline $216-13-1,108-109 \mathrm{~cm}$ & & & & & & & & & & & & & & & & & $x$ & & & & & & & $x$ & $\mathrm{x}$ & & & & & \\
\hline $216-13, \mathrm{CC}$ & & & & & & & & & & & & & & & & & $\mathrm{x}$ & & & & $\mathrm{x}$ & & & $\mathrm{x}$ & $\mathrm{x}$ & & & & & \\
\hline $216 \cdot 14-1,97.98 \mathrm{~cm}$ & & & & & & & & & & & & & & & & & $x$ & & & & $\mathrm{x}$ & $\mathrm{x}$ & & $\mathrm{x}$ & & & & & & 2 \\
\hline $216-14, \mathrm{CC}$ & & & & & & & & & & & & & & & & & $\mathrm{x}$ & & & & $x$ & $x$ & & $x$ & & & & & & 2 \\
\hline $216.15 \cdot 1,80 \cdot 81 \mathrm{~cm}$ & & & & & & & & & & & & & & & & & $|x|$ & $x$ & & & & & & $|x|$ & & & & & & $x$ \\
\hline
\end{tabular}

Figure 6. (Continued). 


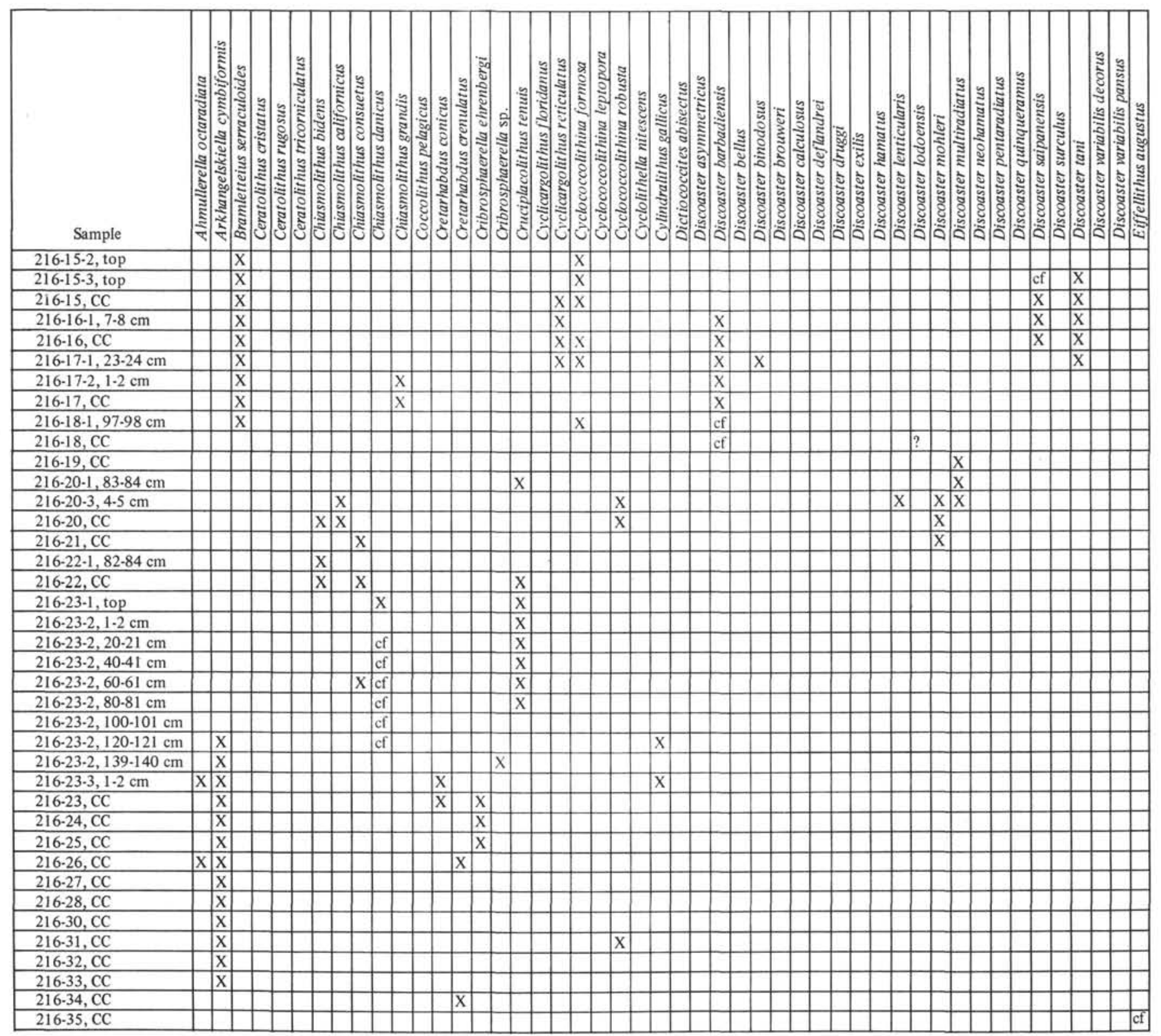

Figure 6. (Continued). 


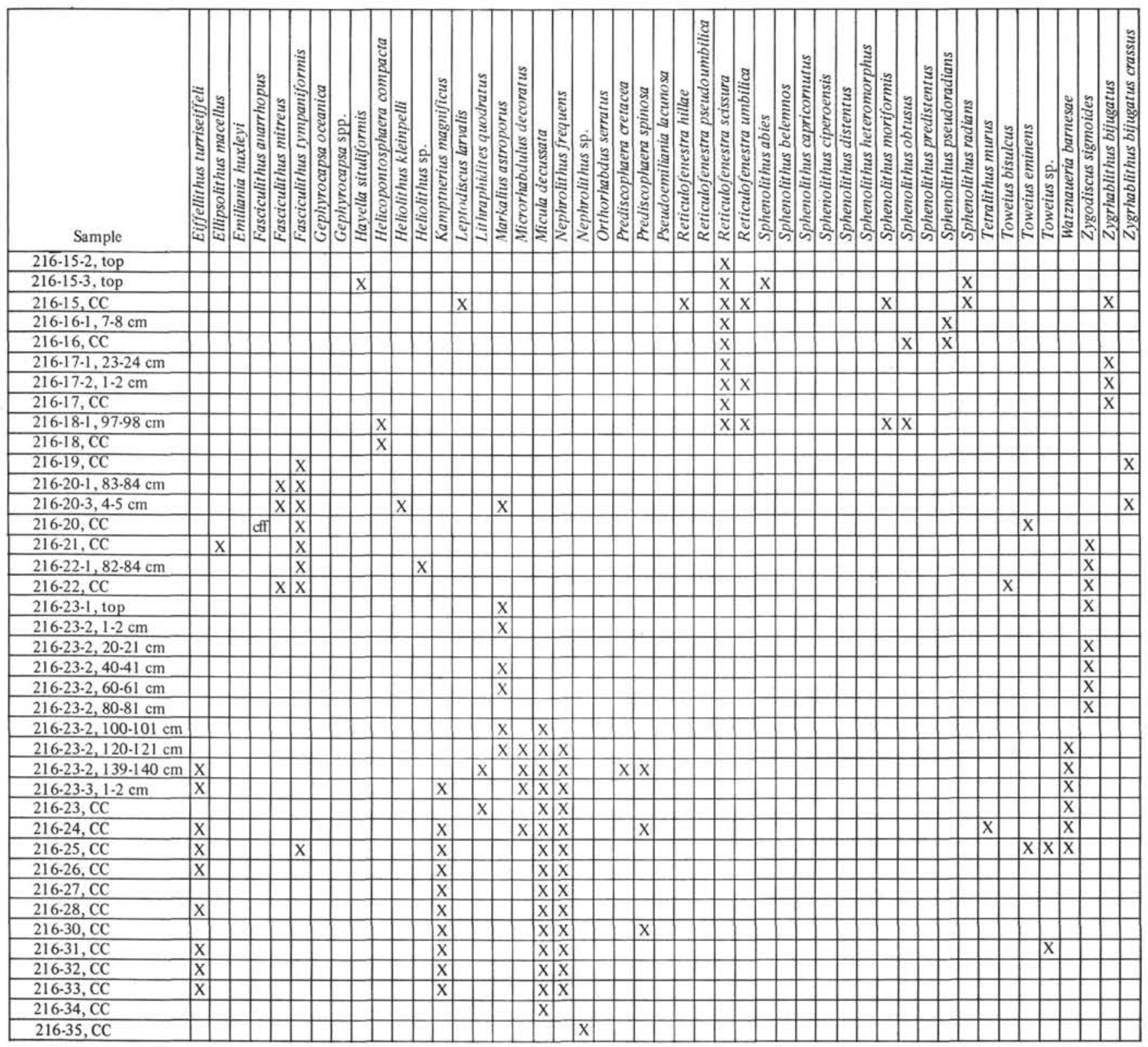

Figure 6. (Continued). 


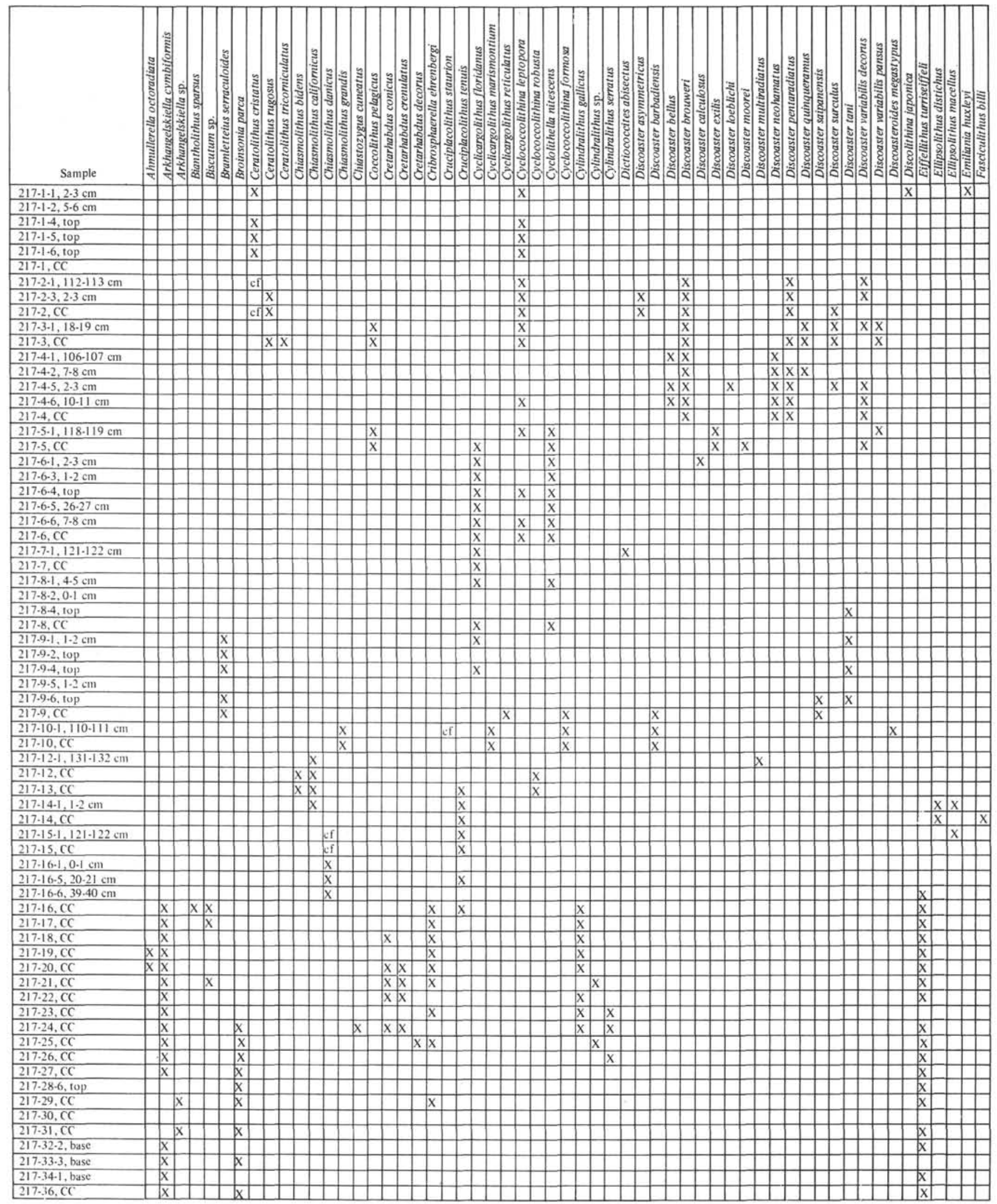

Figure 7. Checklist of calcareous nannofossils recovered at Site 217. 


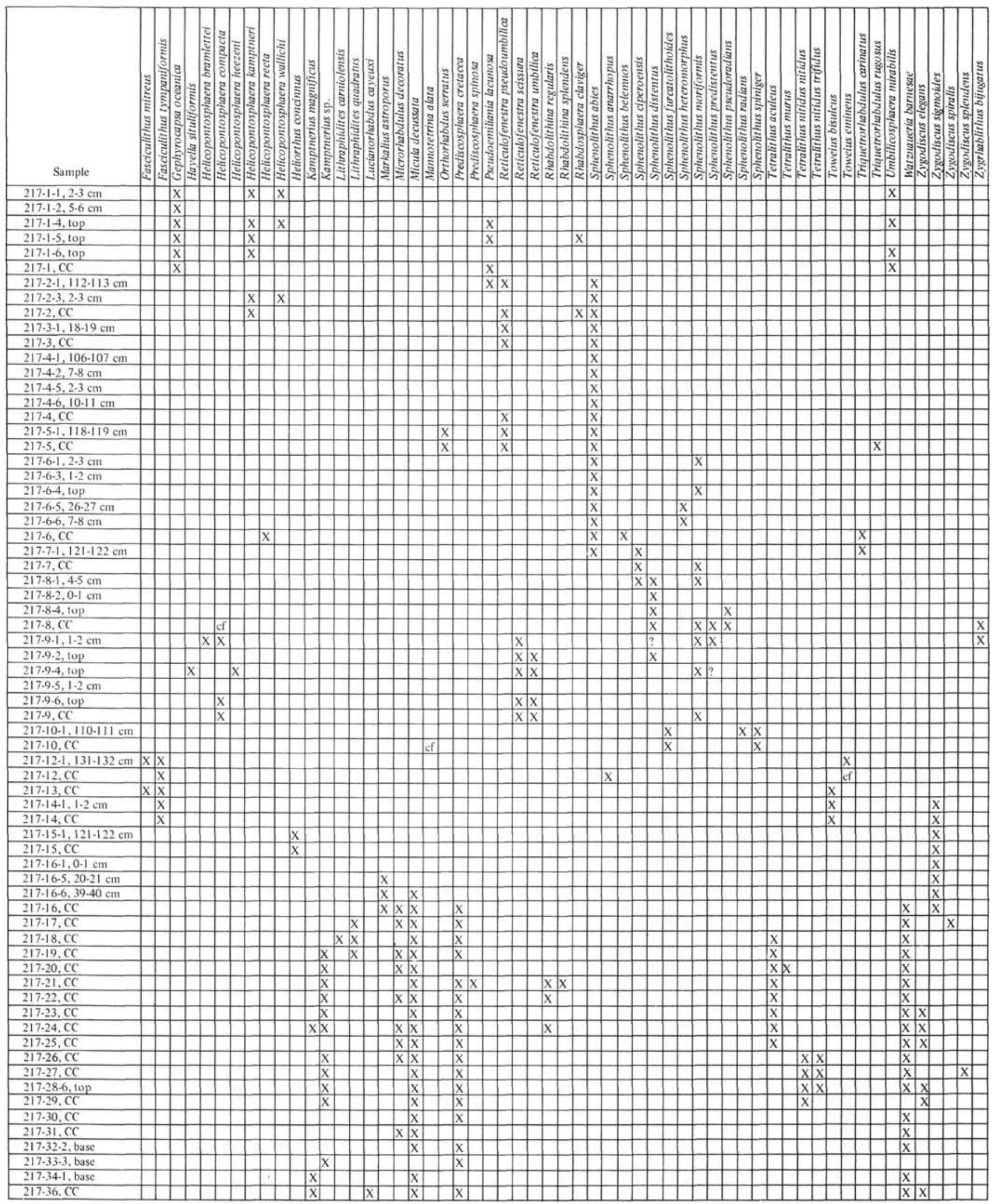

Figure 7. (Continued). 


\begin{tabular}{|c|c|c|c|c|c|c|c|c|c|c|c|c|c|c|c|c|c|c|c|c|c|c|c|}
\hline Sample & 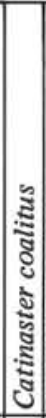 & 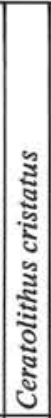 & 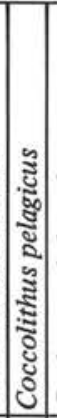 & 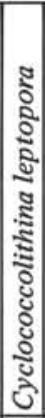 & 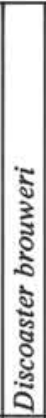 & 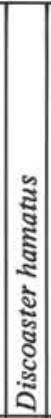 & 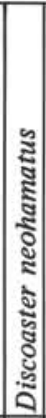 & 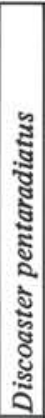 & 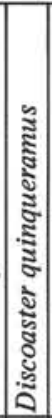 & 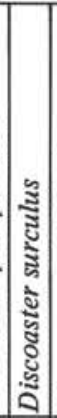 & 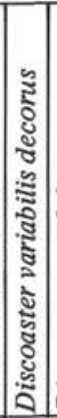 & 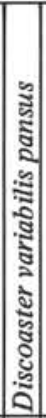 & 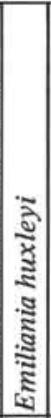 & 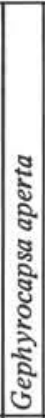 & 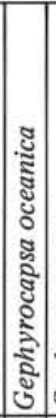 & 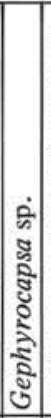 & 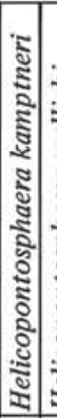 & 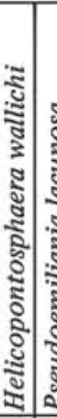 & 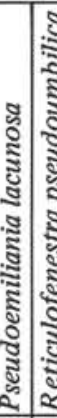 & 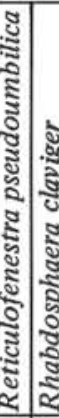 & 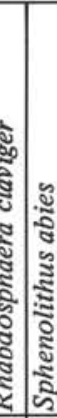 & 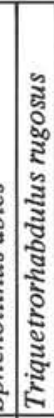 & 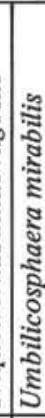 \\
\hline $218-1-1,25$ & & $\mathrm{X}$ & & $\mathrm{X}$ & & & & & & & & & $\mathrm{X}$ & & $\mathrm{X}$ & & \begin{tabular}{|l|l|}
$\mathrm{X}$ & 2 \\
\end{tabular} & $\mathrm{X}$ & & $\mathrm{X}$ & $\mathrm{X}$ & & $\mathrm{X}$ \\
\hline $218-1, \mathrm{CC}$ & & & & $\mathrm{x}$ & & & & & & & & & $\mathrm{X}$ & & $\mathrm{X}$ & & & $\mathrm{X}$ & & & & & $\mathrm{X}$ \\
\hline $218-2, \mathrm{CC}$ & & & & & & & & & & & & & & & $\mathrm{X}$ & & & & & & & & \\
\hline $218-3, \mathrm{CC}$ & & & & & & & & & & & & & & & $\mathrm{X}$ & & & & & & & & \\
\hline $218-4, \mathrm{CC}$ & & & & $\mathrm{X}$ & & & & & & & & & & & $\mathrm{X}$ & & & & & & & & \\
\hline $218-5, \mathrm{CC}$ & & $\mathrm{x}$ & & $\mathrm{X}$ & & & & & & & & & & & $\mathrm{X}$ & & $\mathrm{X}$ & & $\mathrm{X}$ & & & & \\
\hline $218-6, \mathrm{CC}$ & & & & $\mathrm{X}$ & & & & & & & & & & & $\mathrm{X}$ & & $\mathrm{X}$ & & $\mathrm{X}$ & & & & \\
\hline $218-7, \mathrm{CC}$ & & & & & & & & & & & & & & & & $\mathrm{X}$ & & & & & & & \\
\hline $218-8, \mathrm{CC}$ & & & & & & & & & & & & & & $\mathrm{X}$ & & & & & $\mathrm{X}$ & & & & \\
\hline $218-9, \mathrm{CC}$ & & & & & & & & & & & & & & & & & & & & & & & \\
\hline $218-10, \mathrm{CC}$ & & & & & & & & & & & & & & & & & & & & & $\mathrm{X}$ & & \\
\hline $218-11, \mathrm{CC}$ & & & & $\mathrm{X}$ & $\mathrm{X}$ & & & $\mathrm{X}$ & & $\mathrm{X}$ & & & & & & & $\mathrm{X}$ & $\mathrm{X}$ & & $\mathrm{X}$ & $\mathrm{X}$ & & \\
\hline $218-12, \mathrm{CC}$ & & & & & & & & $\mathrm{X}$ & $\mathrm{x}$ & & & & & & & & & & & $\mathrm{X}$ & $\mathrm{X}$ & & \\
\hline $218-13, \mathrm{CC}$ & & & & $\mathrm{X}$ & $\mathrm{X}$ & & & $\mathrm{X}$ & $\mathrm{x}$ & $\mathrm{X}$ & & & & & & & & & $\mathrm{X}$ & & $\mathrm{X}$ & & \\
\hline $218-14, \mathrm{CC}$ & & & $\mathrm{X}$ & $\mathrm{X}$ & $\mathrm{X}$ & & & & $\mathrm{x}$ & $\mathrm{X}$ & & $\mathrm{X}$ & & & & & & $\mathrm{X}$ & & $\mathrm{X}$ & $\mathrm{X}$ & & \\
\hline $218-15, \mathrm{CC}$ & & & & & & & & & $\mathrm{x}$ & & & & & & & & & & & & $\mathrm{X}$ & & \\
\hline $218-16, \mathrm{CC}$ & & & & & & & $\mathrm{X}$ & $\mathrm{X}$ & $\mathrm{X}$ & $\mathrm{X}$ & $\mathrm{X}$ & $\mathrm{X}$ & & & & & $\mathrm{X}$ & & & $\mathrm{X}$ & $\mathrm{X}$ & $x$ & \\
\hline $218-18, \mathrm{CC}$ & & & & & $\mathrm{X}$ & & & $\mathrm{X}$ & & $\mathrm{X}$ & & & & & & & $\mathrm{X}$ & & & & $\mathrm{X}$ & & \\
\hline $218-19, \mathrm{CC}$ & & & & & $\mathrm{X}$ & & & & $\mathrm{x}$ & & & & & & & & & & & $\mathrm{X}$ & $\mathrm{X}$ & & \\
\hline $218-21, \mathrm{CC}$ & & & & & $\mathrm{X}$ & & & $\mathrm{X}$ & & & & & & & & & & & & $\mathrm{X}$ & $\mathrm{X}$ & & \\
\hline $218-23, \mathrm{CC}$ & & & & $\mathrm{X}$ & $\mathrm{X}$ & & $\mathrm{X}$ & $\mathrm{X}$ & & $\mathrm{x}$ & $\mathrm{X}$ & & & & & & & & & $\mathrm{X}$ & $\mathrm{X}$ & & \\
\hline $218-24, \mathrm{CC}$ & & & & & $\mathrm{x}$ & & & $\mathrm{X}$ & & & & & & & & & & & & $\mathrm{X}$ & $\mathrm{X}$ & & \\
\hline $218-25, \mathrm{CC}$ & & & & & $\mathrm{X}$ & $\mathrm{x}$ & & & & & & & & & & & & & & $\mathrm{X}$ & $\mathrm{X}$ & & \\
\hline $218-26, \mathrm{CC}$ & $\mathrm{x}$ & & & & & & & & & & & & & & & & & & & $\mathrm{X}$ & & & \\
\hline $218-27, \mathrm{CC}$ & & & & & & & & & cff & & & & & & & & & & & & & & \\
\hline
\end{tabular}

Figure 8. Checklist of calcareous nannofossils recovered at Site 218. 


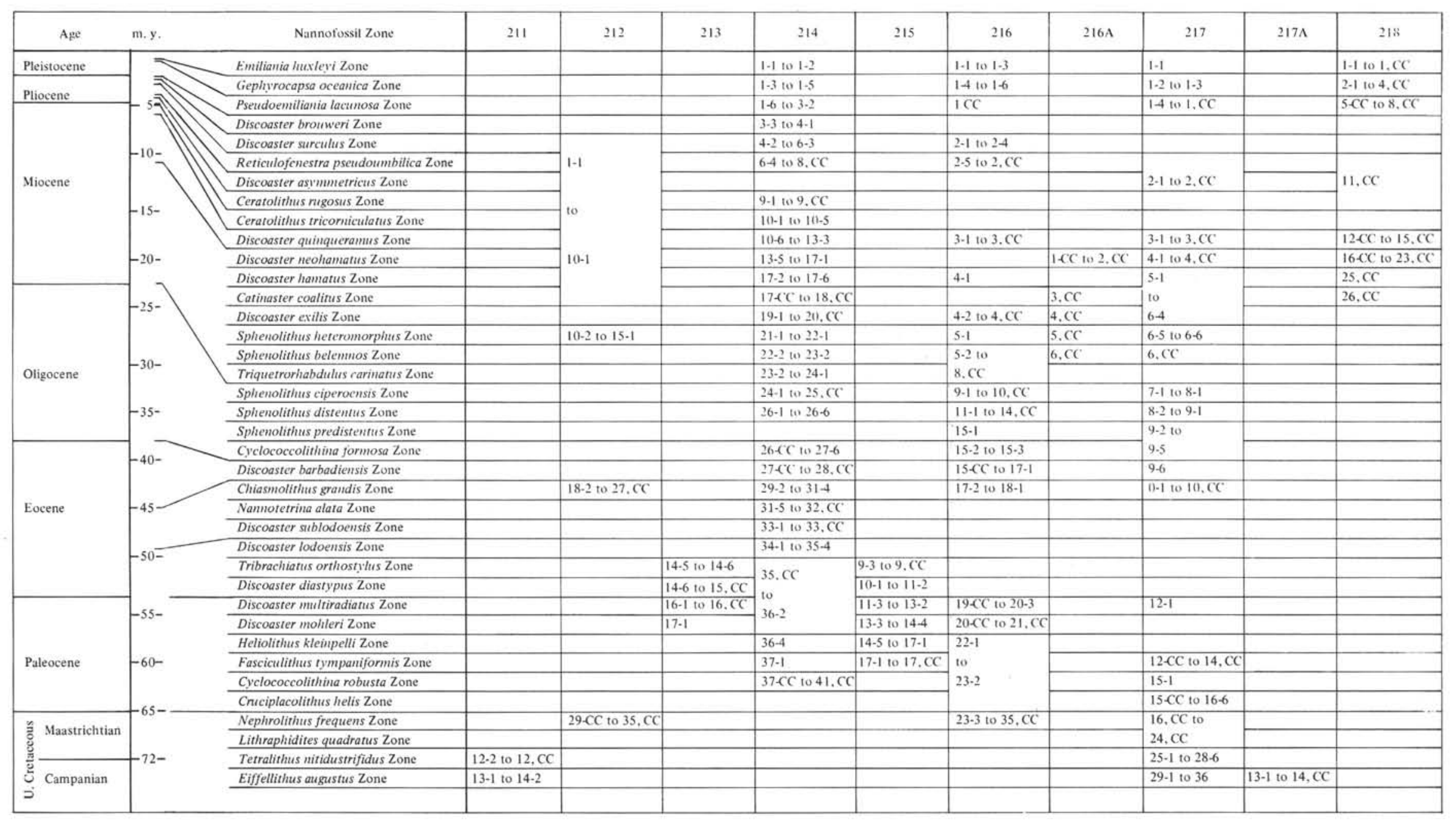

Figure 9. Summary correlation chart based on calcareous nannofossils of sites drilled on Leg 22, DSDP. 

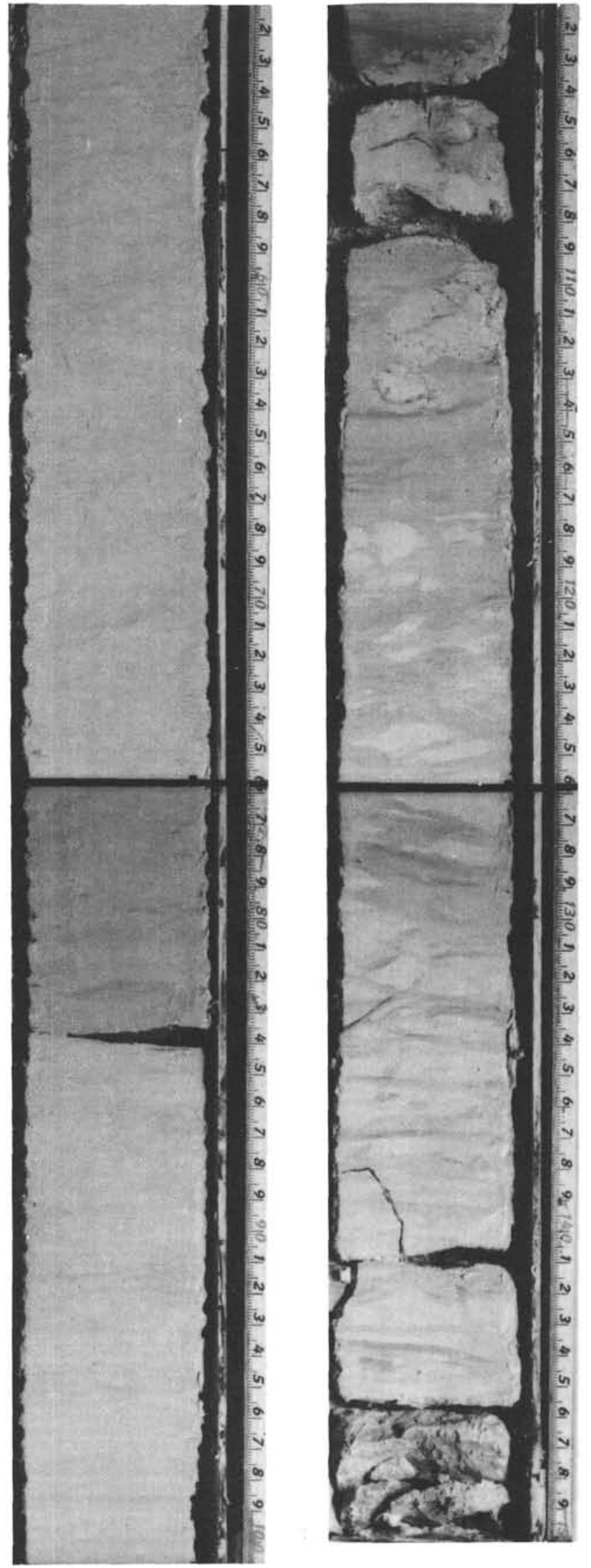

Figure 10. Core photograph across Cretaceous-Tertiary Boundary at Site 216, Sample 32-2, 61-150 cm. 


\section{APPENDIX 1}

Nannofossil species identified in sediment recovered during Leg 22 (listed in Alphabetical order).

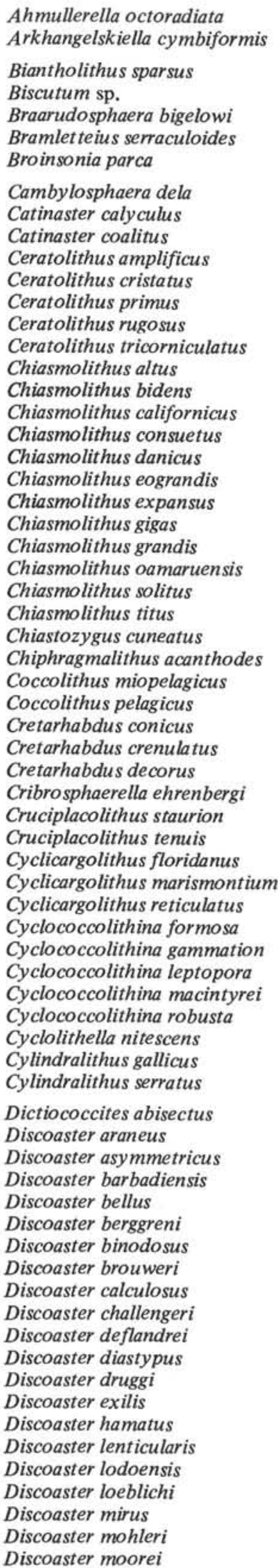

Discoaster multiradiatus

Discoaster neohamatus

Discoaster neorectus

Discoaster ornatus

Discoaster pentaradiatus

Discoaster quinqueramus

Discoaster saipanensis

Discoaster sublodoensis

Discoaster surculus

Discoaster tamalis

Discoaster tani

Discoaster variabilis decorus

Discoaster variabilis pansus

Discoasteroides kuepperi

Discoasteroides megastypus

Discolithina japonica

Eiffellithus augustus

Eiffellithus turriseiffeli

Ellipsolithus distichus

Ellipsolithus macellus

Emiliania huxleyi

Fasciculithus billi

Fasciculithus mitreus

Fasciculithus tympaniformis

Gephyrocapsa aperta

Gephyrocapsa caribbeanica

Gephyrocapsa oceanica

Hayella situliformis

Helicopontosphaera bramlettei

Helicopontosphaera compacta

Helicopontosphaera granulata

Helicopontosphaera heezeni

Helicopontosphaera kamptneri

Helicopontosphaera recta

Helicopontosphaera wallichi

Heliolithus kleinpelli

Heliolithus riedeli

Heliorthus concinnus

Heliorthus distentus

Heliorthus fallax

Isthmolithus recurvus

Kamptnerius magnificus

Leptodiscus larvalis Lithraphidites carniolensis

Lithraphidites quadratus

Lophodolithus nescens

Lucianorhabdus cayeuxi

Markalius astroporus

Microhabdulus decoratus

Micula decussata

Nannotetrina alata

Nephrolithus frequens

Oolithotus antillarum

Orthorhabdus serratus

Peritrachelina sp.

Prediscosphaera cretacea

Prediscosphaera spinosa

Pseudoemiliania lacunosa

Reticulofenestra hillae

Reticulofenestra pseudoumbilica

Reticulofenestra samodurovi

Reticulofenestra scissura

Reticulofenestra umbilica

Rhabdolithina regularis

Rhabdolithina splendens

Rhabdosphaera claviger

Scyphosphaera amphora Sphenolithus abies 
Sphenolithus anarrhopus

Sphenolithus belemnos

Sphenolithus capricornutus

Sphenolithus ciperoensis

Sphenolithus distentus

Sphenolithus furcatolithoides

Sphenolithus heteromorphus

Sphenolithus moriformis

Sphenolithus obtusus

Sphenolithus pacificus

Sphenolithus predistentus

Sphenolithus pseudoradians

Sphenolithus radians

Sphenolithus spiniger

Tetralithus aculeus

Tetralithus murus

Tetralithus nitidus nitidus

Tetralithus nitidus trifidus
Tetralithus quadratus

Thoracosphaera oblonga

Toweis bisulcus

Toweius craticulus

Toweius eminens

Tribrachiatus orthostylus

Triquetrorhabdulus carinatus

Triquetrorhabdulus milowi

Triquetrorhabdulus rugosus

Umbilicosphaera mirabilis

Watznaueria barnesae

Zygodiscus elegans

Zygodiscus sigmoides

Zygodiscus spiralis

Zygrhablithus bijugatus

Zygrhablithus bijugatus crassus 